\title{
Türkiye’deki Suriyelilerin Sosyolojik “Yabancı” Olarak Ele Alınması Üzerine Eleştirel Bir Değerlendirme ${ }^{1}$
}

\section{A Critical Assessment on Addressing Syrians in Turkey as Sociological "Stranger"}

\author{
Özlem KAHYA NIZAM* \\ Songül SALLAN GÜL** \\ * Süleyman Demirel Üniversitesi Fen Edebiyat Fakültesi, Sosyoloji Bölümü, ozlemkahya@,sdu.edu.tr \\ ** Süleyman Demirel Üniversitesi Fen Edebiyat Fakültesi, Sosyoloji Bölümü, songulsallangul@yahoo.com \\ ORCID Numaraları | ORCID Numbers: *0000-0002-7604-3678/**0000-0003-1107-7372
}

Öz: 2011 yılından bu yana Suriyelilerin Türkiye'ye zorunlu göçü, Türkiye'yi kitlesel bir göç akını ile karșı karşıya bırakmıștı. Bașlangıçta, ülkelerindeki durum düzeldiğinde geri dönecekleri düşünülen Suriyeliler, hem siyasal hem de toplumsal alanda "misafir" söylemi ile birlikte ele alınmıştır. Ancak süreç içerisinde, Suriye'deki durumun düzelmemesi ve yakın zamanda düzeleceğine dair olan öngörünün sorgulanması, nüfusları yaklaşık 4 milyona ulaşan Suriyelilerin Türkiye'deki kalıcılıklarına ilişkin tartışmaları beraberinde getirmiş̧ir. Akademik çalışmalarda da toplumsal bütünleşme, toplumsal uyum, birlikte yaşama gibi temalar çerçevesinde konuya yoğun bir ilgi oluşmuştur. Son yıllarda sosyoloji alanında yapılan çalıșmalarda ise, Suriyeliler, farklılaşan özelliklerine referansla, Simmel, Park ve Bauman'ın geliștirdiği yabancılık teorileri bağlamında "yabancı" kavramı ile özdeşleştirilerek ele alınmaya başlamıştır. Bu çalışmada, yabancı teorilerinin ortaya çıktığı ulusal durumlar ve Türkiye deneyiminin dinamikleri çerçevesinde "yabancı" kavramının Suriyeliler için kullanımının ne derece uygun olduğu tartışılmaktadır. Bu makalenin temel iddiası, yabancılık tartışmalarının ortaya çıktığı ülkelerin uluslararası göç ve göçmenlik deneyiminin Türkiye'ninkinden oldukça farklı olduğu ve Suriyelilerin sosyolojik anlamda "yabancı" olarak tanımlanıp tanımlanamayacağını anlamak için uzun bir tarihselliğe ihtiyaç duyulduğudur.

Anahtar Kelimler: Uluslararası Göç, Suriyeli, Simmel, Park, Bauman, Yabancl

Abstract: Since the year 2011, forced migration of the Syrians to Turkey has had the country confronted a massive influx of immigration. Initially, the Syrians, who were supposed to return when the situation in their country to be improved, were dealt with the "guest" discourse in both political and social spheres. But in the process, failing the improvement of the situation in Syria and questioning the prediction about finding a remedy in the near future has raised a question related to the persistency of the Syrians whose population has reached about 4 million in Turkey. In academic studies, there has also been an intense interest in the subject within the framework of themes such as social integration, social cohesion and living together. In recent years, in the studies carried out in the field of sociology, the Syrians, who are identified with the concept "stranger" with the reference of their differentiating characteristics, have started to be discussed in the context of theories of alienation developed by Simmel, Park and Bauman. In this study, the use of the concept "stranger" for the Syrians is discussed within the frame of national situations in which alienation theories emerge and dynamics of Turkey's experience. The main claim of this article is that the experience related to international migration and immigration of the countries where theories of alienation emerged is quite different from that of Turkey and a sound historicity is needed to understand whether the Syrians to be defined as "stranger" in the sociological concept.

Key Words: International Migration, Syrian, Simmel, Park, Bauman, Stranger

\footnotetext{
${ }^{1}$ Bu makale Süleyman Demirel Üniversitesi Sosyal Bilimler Enstitüsü Sosyoloji Anabilim Dalı’nda danışmanlığı Prof. Dr. Songül Sallan Gül tarafından yapılan, Özlem Kahya Nizam'ın SDÜ ÖYP Koordinatörlüğ̈̈ tarafindan desteklenen ÖYP05247DR-14 Nolu “Türkiye'de Milliyetçiliğin Dönüşümünü Uluslararası Göçler Üzerinden Okumak: İzmir Örneği” adlı Doktora tezi projesinin kuramsal kısmından üretilmiştir.
} 


\section{GİRIŞ}

1980'lere kadar uluslararası göçlerde kaynak ülke olarak ön plana çıkan Türkiye, sonraki süreçte jeostratejik coğrafi konumunun da etkisi ile transit ve hedef ülke konumu kazanmaya başlamıștır. 2000'li yıllarla giderek artan ve çeşitlenen göç hareketlerine sahne olurken, 2011 yılı sonrasında ise, Suriyelilerin kitlesel göçü ile zorunlu göçün merkez ülkesi haline dönüşmüştür. Türkiye'nin uluslararas1 göç deneyiminde meydana gelen bu farklılaşma, Türkiye'de yaşayan göçmen profilinin de dönüşümünü beraberinde getirmiştir. Türkiye tarihsel olarak, göçmenlik politikasını "Türk soyundan olma ve/veya Türk kültürüne bağlı olma" üzerinden şekillendirmiş, bu kritere uygun olanları göçmen olarak kabul etmiş ve yerleşimlerine izin vermiştir. İltica politikalarında ise, "Avrupa'da meydana gelen olaylar nedeniyle" gelen sığınmacılara mülteci statüsü vermeyi tercih etmiş, bu ülkeler dışından gelenleri "şartlı mülteci", "geçici koruma", "ikincil koruma" gibi uzun vadede Türkiye'de kalmayı garanti etmeyen yasal statüler altında tanımlamıştır (Yabancılar ve Uluslararası Koruma Kanunu, 2013, Madde 61-62-63). Göçmen olarak kabul edilenlerin etnisite temelinde ülkenin genel nüfus profiline benzer, mülteci olarak kabul edilenlerin ise, nicelik olarak oldukça sınırlı oluşu, uluslararası göçler ile gelenlerin Türkiye toplumu ile birlikte yaşama deneyiminin yakın zamana kadar göz ardı edilmesine yol açmıştır. Ancak Suriyelilerin yoğun kitlesel göçü ve yaklaşık 4 milyona ulaşan nüfusun Suriye'ye geri dönüşlerinin yakın gelecekte olanaklı görülmemesi Türkiye'nin ilk kez bir göçmen gruba yönelik birlikte yaşamı tartışmasını beraberinde getirmiş ve göçmenlerin nasıl tanımlanacağı ve değerlendirilmesi gereğini tartışmaya açmıştır.

Türkiye'de göçün/göçmenliğin sosyolojik olarak dönüşümü, yapılan sosyolojik araştırmalarda Suriyelilerin Türkiye toplumu ile etkileşimi, toplumsal bütünleşme, uyum ve dişlanma gibi temalar çerçevesinde tartışmaya açılmasını beraberinde getirmiştir (bknz: Apak, 2014; Çetin, 2016; Açıkgöz vd. 2017; Sağır ve Kurtkara, 2018; Tümtaş, 2018; Bakioğlu vd. 2018). Sosyoloji/Sosyal Bilimler alanında çalışan bazı araştırmacılar ise, kuramsal arka planlarını oluştururken Simmel, Park ve Bauman'ın katkıları ile geliştirilen "yabancı" kavramını temel almaya başlamış, Türkiye'deki Suriyelileri, Türkiye toplumu tarafından dışlanmalarına ve ötekelileştirilmelerine referansla sosyolojik "yabancı" ile ilişkilendirmiştir (Ünal, 2014; Man, 2015; Göker ve Keskin, 2015; Altunkaynak, 2016; Kahraman ve Kahya Nizam, 2016; Gözübüyük Tamer, 2016; Ekinci vd, 2017; Kaya 2017). Bu noktada "yabancı" kavramı ile ilgili bir ayrımın üzerinde durmak yerinde olacaktır. 5901 Sayılı 2009 Tarihli Türk Vatandaşlı̆ğ Kanunu'na göre, Türkiye Cumhuriyeti Devleti ile vatandașlık bağı bulunmayan her kiși yabancıdır (Madde 3/d). Bu durumda Suriye'den göç ile gelen Suriye Arap Cumhuriyeti vatandaşlarının tümü hukuksal statü bağlamında yabancıdır. Ancak bu makalede Suriyelilere ilişkin tartışılan, hukuksal olarak yabancı olmaları değil, sosyolojik "yabancı" olarak tanımlanıp tanımlanamayacaklarıdır. Bu makale, Türkiye'deki Suriyeliler örneğinde yabancı kavramının temel alınmasının Türkiye'nin sosyolojik koşulları içerisindeki olanaklılığını tartışmaya açmayı amaçlamaktadır. Bu amaçla ilk olarak yabancilık sosyolojisinin temel isimleri olan Simmel, Park ve Bauman'ın yabanciya ilişkin tartışmalarına yer verilmekte, sonrasında ise, teorik tartışmaların geliştiği ülkelerin bağlamları ile Türkiye deneyiminin bir karşılaştırması yapılarak Suriyelilerin sosyolojik "yabancı" olarak tanımlanıp tanımlanamayacakları sorgulanmaktadır. Makalede ayrıca, Türkiye'de Suriyeliler üzerine yapılmış sosyoloji/sosyal bilim araştırmalarından online olarak erişilebilir olan ve söz edilen sosyologların "yabancı" tipolojisini ele alan çalışmalara da değinilmektedir. Bu çalışmaların tümü, Suriyeliler ile birlikte yaşamın Türkiye toplumundaki karşılığını ortaya koyması açısından katkı sağlamakta ve önem taşımaktadır. Makale kapsamında "yabancı" kavramının genel bir tanımı üzerinden gitme noktasına eleştiriler getirilerek literatüre katkı sağlamak amaçlanmaktadır.

\section{Yabanci Sosyolojisinde Göçmenliğin Görünümleri}

Evsahibi toplumun göçmenlere yönelik bakış açısını tartışan literatür ağırlıklı olarak "yabancı" kavramı temel almakta, sonradan gelen kişiler olarak göçmenlerin ağıllkklı olarak "yabancı" olarak değerlendirildiği görülmektedir. Sosyolojik tartışmalarda Simmel, Park ve Bauman'ın yabancılığa ilişkin fikirleri araştırmacılar için teorik arka planı inşa ederken sıklıkla kullanılmakta, nitekim bu sosyologların fikirleri Yabanc1 Teorileri (Theories of Stranger) olarak adlandırılmaktadır (Marotta, 
2017). Göç alan toplumun göçmenlerle birlikte yaşama deneyimi ise, yabancılık üzerinden tartışılmaktadır. Göçmenin toplumsal konumu bu bağlamda, içeride olan, ama aynı zamanda marjinal, ikincil konumda kalan, dışarıdaki, öteki olarak şekillenmektedir (Rapoport ve Lomsky-Feder, 2001).

\subsection{Georg Simmel: Etkileşime Dayalı Birliktelik Biçimi Olarak Yabancı}

Simmel 1908 yılında ele aldığg "The Stranger” (1908) adlı çalışmasında yabancının sosyolojik biçimini, "mekanda verili her noktadan belli bir uzaklıkta olma durumu" ile "belli bir noktaya bağlılığın olmaması" durumunun sentezi olarak tanımlamaktadır (Simmel, 2009: 149). Simmel'in yabanc1 analizinde mekânın ve mekânda kurulan ilişkilerin önemli bir yeri vardır. Simmel'e göre mekân ilişkileri, insan ilişkilerinin simgesidir. Mekânda bulunuşu, yabancının tanımlanmasında merkezi bir konuma alan Simmel'e göre yabanc1, "burada sayılmaz, ancak bugün gelip yarın giden gezgin gibi de değildir; bugün gelip yarın kalan insan gibidir”. Bir diğer deyişle yabancı, daha öteye gitmeyecek olsa da "gelip gitme özgürlügünü tam edinememiş potansiyel gezgin" gibidir (Simmel, 2009: 149). Mekânsal ilişkiler içerisinde yabancının toplumsal konumunu belirleyen ise, grup üyeliğidir. Simmel'e göre yabanc1, sınırları belli bir mekân ya da grup içerisinde konumlanmıştır ancak en başta ona ait olmamasının ve baştan beri onun bir parçası olmayan/olamayacağı nitelikler taşımasının etkisi altındadır (Simmel, 2009: 149). Bu açıdan Simmel'in yabancısı, sosyal sınırları çizen kişidir (Rapoport ve Lomsky-Feder, 2001).

Simmel, yabancıyla olan etkileşimi ele alırken mesafe kavramını merkezine alır. Yabancı ile aradaki mesafe, uzaklık-yakınlık derecesi birliktelik biçimlerini etkiler. Simmel'e göre, her insan ilişkisinin barındırdığı yakınlık-uzaklık ilişkisinin en özlü biçimde yapılanmasını ortaya koyan ise, yabancıdır. Yabancılık ilişkisinde yabancı, yakın olanın uzak ama yabancı olarak görülebilecek kadar da yakın olmasına işaret etmektedir. Burada yabancılık ilişkisi, bütünüyle olumlu özgül bir etkileşim biçimidir ${ }^{2}$. Simmel'e göre yabancılık ilişkisinin ortaya çıkabilmesi için mesafe içerisinde karşılıklı yönelimliliğin varlığı oldukça önemlidir. Her şeyden önce bir kişinin/halkın yabancı olarak tanımlanabilmesi için yabancıların varlığı ile yüzleşilmesi gerekir. Nitekim yabancının sosyolojik olarak ele alınmasını sağlayan da bu birliktelik biçiminin beraberinde getirdiği etkileşimdir. Yabanc1, bizzat grubun kendisinin bir unsurudur. Onun grup içindeki üyeliği hem dışında olmayı hem de yüzleşmeyi içeren bir niteliğe sahiptir. Başka bir deyişle, varlığından haberdar olunmayan, etkileşime girilmeyen bir halk, yabancı olamaz (Simmel, 2009: 149). Bu durumda sahip olduğu özellikler dolayısıyla yabancı ne çok yakın ne de çok uzak bir tip olarak karşımıza çıkar. Eğer çok yakın olsa yabancı olmayacak olan bu kişi, çok uzak olsaydı da grupla teması/etkileşimi kesilecek olan kişiyle aynı kişidir. Bu açıdan yabancının grup üyeleri ile girdiği etkileşim, yakınlık ve mesafenin bir birleşimini içerir (Ritzer, 2014: 278).

Yabancının grupla olan uzaklık ve yakınlığının beraberinde getirdiği bir diğer özellik, yabancının nesnelliğidir. Yabancı, grubun belli bileşenlerine ve yatkınlıklarına bağlanmış bir kişi değildir. $\mathrm{Bu}$ açıdan bir nesnelliği söz konusudur; olay ve durumları tarafsız bir şekilde değerlendirebilir. Olaylara önyargılı bir biçimde bakmasına neden olacak bağlarla bağlı değildir. Eylemleri, dinsel teamüller, önceki örnek olaylar veya gelenekler tarafindan sınırlanmaz. Yabancıllğın nesnelliği ise, onu daha özgür k1lar (Simmel, 2009: 150-151)³.

Simmel'e göre, grup ile yabancı arasındaki yakınlık ve uzaklık orantısı, yabancı ile kurulan ilişkilerin daha soyut doğasında da pratik ifadesini bulur. Öyle ki yabancıyla ortak olan sadece ve sadece daha genel niteliklerdir. Bir başka ifadeyle, insan yabancıyla sadece belli, daha genel nitelikleri paylaşırken,

\footnotetext{
2 Makale içerisinde yer alan tüm italik yazılar, makale yazarları tarafından tartışmanın temel noktalarını vurgulamak amacıyla yapılmıştır. Simmel, Park ya da Bauman’ın orijinal metinlerinde italik olarak yer almamaktadir.

${ }^{3}$ Simmel, bu özgürlük durumunun yabancıyı tarihsel süreçlerde tehlikeli olasılıklarla karşı karşıya getirdiği üzerinde de durmaktadır. Ona göre yabancılar, toplumlar/uluslar tarafından her türden başkaldırma esnasında ilk saldırılan taraf olmakta; ayaklanmanın dışarıdan gelen, yabancı temsilciler ve provokatörler tarafından kışkırtıldığı yönünde söylemlerle karşılaştırmaktadır. Simmel, bunun bazı durumlarda geçerli olabileceğini kabul etmekle birlikte, yabancının özel rolünün abartılarak yorumlandığı da ileri sürer (Simmel, 2009: 151).
} 
organik bağı olan kişilerle ilişkisi tam da onları genel olandan ayıran özgül benzerliğine dayanır. Bu bağlamda ortaklığın ilişki üzerindeki etkisi, yabancı ile ilişkinin doğasını belirlemektedir. Simmel ortaklığa yüklenen anlamı şu şekilde ifade etmektedir: "Yabancı, o ve kendimiz arasında, millet ve sosyal konum benzerlikleri, iş ya da genel insan doğası temelli benzerlikler hissettiğimiz ölçüde bize yakındır. Bu benzerlikler, bizim ve onun ötesine genişlediği ölçüde ve bizi birbirimize çok sayıda insanı bağladığı gibi sıradan bir şekilde bağladığı ölçüde, aslında uzaktır” (Simmel, 2009: 152).

Tüm bu tartışmalara göre Simmel'in yabancısı, esasen olumlu bir birliktelik biçimine karşıllk gelir. Ancak o, olumlu olmayan bir yabancılık türünden de bahsetmektedir. Göçmenlere yönelik ayrımcılık, eşitsizlik ve dışlama gibi konuları ele alan çalışmaların temel aldığı yabancı tipi genellikle olumsuz yabancılık tipidir. Genel bir nitelik temelinde kurulan irtibatın baştan dışarıda bırakıldığı olumlu olmayan bu yabancılık türünde yabancı ile ilişki "yok-ilişkidir". Simmel bu yabancılık türüne Yunanlılar ile Barbarların ilişkisini örnek vermektedir. Burada yabancı tabirinin olumlu bir anlamı yoktur. Burada yabanc1, grubun bir üyesi olarak ele alınan yabancı değildir (Simmel, 2009: 153). Bu yabanc1lık türünde insana özgü sayılan genel niteliklerin yabanc1 için kabul edilemez olduğu düşüncesi ön plandadır. Yabancının böyle görüldüğü durumlarda aslında onunla kurulamayan bir ilişkisizlik söz konusudur. Buradaki yabancı, Simmel'in temel aldığı ve olumlu bir ilişki biçimi olarak tanımladığı yabancıdan farklıdır. Bu yabancılık türünde yabancı, grubun içerisinde olmayan, bizzat grubun bir üyesi olarak tanımlanmayan bir yabancıdır. Genel insani benzerliklerin, bir ülkeye, bir şehre, bir ırka yabancı olmak gibi, ortak olmayana vurgunun yapıldığı bir durumun arkasında kaldığ 1 zamanlarda bu yabancılık türü ortaya çıkar. Burada yabancılık bireysel bir şey değildir, yabancının kendisi gibi olan diğer yabancılarla ortaklaştığı ya da ortaklaşabileceği bir nitelik olarak kökeninin yabancılığına karşılık gelir. $\mathrm{Bu}$ durum Simmel'e göre yabancıların birey olarak değil, belli bir toplumsal tip olarak görülmelerine neden olur (Simmel, 2009: 153).

Simmel bir toplumsal tip olarak yabancyya Yahudileri örnek gösterir. Simmel düşüncesini Ortaçağ döneminde Frankfurt ve başka yerlerde Yahudilere uygulanan vergi uygulamasının Hıristiyanlara uygulanandan farklı olması örneği üzerinden açıklar. Hıristiyanların mal varlıklarına göre vergi öderken, Yahudilerin tek tip bir vergi ödemeye tabi tutulması ona göre Yahudilerin toplumsal konumundan kaynaklanmaktadır. Yahudilerin farklılaşan ve ağırlaşan vergi yükümlülükleri, belirli nesnel içeriklerin taşıyıcısı olmasıyla değil, her şeyden önce bir Yahudi olmasından dolayıdır. Bu yabancılık ilişkisinde tek tek Yahudilerin içindeki bulundukları koşulların farklılıkları dikkate alınmaz. Dolayısıyla, Simmel'e göre yabancıyla kurulan ilişkiye özgül biçimini veren şey, uzaklıkla yakınlık arasındaki özel orantı ve yine aralarındaki gerilimdir (2009: 154).

\subsection{Robert Ezra Park: Kültürel Etkileşim Kıskacında Marjinal İnsan Olan Göçmen}

Robert Ezra Park, Simmel'in yabancı tartışmasından yola çıkarak 1928 tarihli "Human Migration and Marginal Man" adlı çalışmasında Marjinal İnsan Teorisi'ni (Marginal Man Theory) geliştirmiştir. Park'ın yaklaşımı, Amerikan kentlerinin aldığı yoğun göçler sonrası, göçmenlerin Chicago'daki kentsel ve toplumsal uyumlarının dinamiklerini ortaya koymaktadır. Bu dönemde Chicago kenti, İtalyanlar, İlandalılar, Polanyalılar, Ukraynalılar ve başka ülkelerden gelen göçmenlerin akımları ile karşılaşmış, muazzam bir etnik heterojenliğe tanık olmuştur (Weisberger, 1992: 428).

Park'ın marjinal insan kişilik tipinin, kentsel toplumsal düzen ve değişme analizinde oldukça önemli bir araç olduğu söylenebilir. Park, göçler sonucu meydana gelen kültürel farklılaşma ve etkileşimi sosyolojik yaklaşımı bağlamında iki yönlü olarak ele almaktadır. Bunlardan ilki, göçlerin toplumsal yönüdür. Göçlerin toplumsal yönünü, farklı kültürel arka plana sahip insan topluluklarının sosyal temas1 oluşturur. Sosyal temas, en temel toplumsal süreç olan etkileşimin ilk aşamasıdır. Bu bağlamda, toplumsal etkileşimin sonraki aşamalarını şartlandırır ve kontrol eder (Park, 2019: 73). Göç sonrasında göç edilen toplumun toplumsal düzeninin yeni gelenler aracılığıyla yıkımı söz konusu olsa da, temas ve etkileşim süreci, yerli ve yabancı halkların kaynaşmasıyla tamamlanır. Park'a göre her millet bir eritme potasına sahiptir ve bu sayede eninde sonunda kültürel asimilasyon gerçekleşecektir (Park, 2016: 71). Ekonomik ve siyasal asimilasyonun gerçekleşmesini sağlayacak olan ise, ortak ekonomi ve toplumsal iş bölümüdür. Park'a göre göç, fethetmeye yol açtığında ekonomik ya da siyasal asimilasyon da kaçınılmazdır. Ona göre uzun vadede birlikte yaşayan, aynı ekonomiyi paylaşan halklar ve ırklar 
kaçınılmaz olarak melezlenecektir. Bu durum insanların her şey için olmasa da ekonomik ilișkilerin varlığı sayesinde sosyal ve kültürel ilişkilerin varlığına yol açan bir niteliğe sahiptir. Egemen ve tebaa halk zaman içerisinde bir toplumun ayrılmaz ve tamamlayıcı parçaları haline gelir (Park, 2016: 80).

Göçmenlerle birlikte yaşamın sağlanması, başlangıçta bir rekabet ve çatışma ortamı oluşsa da, süreç içerisinde iki grubun birbirine uyum sağlaması ve göçmenlerin asimile olarak ortak bir kültürde birleşmesi ile mümkün görünmektedir. Rekabet, çatışma, uyum ve asimilasyon, Park'ın genel ontolojiksosyolojik yaklaşımının temel dayanaklarıdır. Topluluk, toplum formunu bu süreçler aracılığıyla kazanır (Park ve Burgess, 2017: 71). Park'a göre asimilasyonun gerçekleşmesini sağlayan ise, insan topluluklarının çift yönlülüğüdür: birbirleri ile rekabet ve çatışma içinde olan insanlar, "aynı zamanda simgesel yollarla onaylanmış dayanışma, oydaşma ve ortak amaç tarafindan bir birlik içinde tutulan, birbirlerine karşıllklı olarak bağımlı olan kişiler ve gruplardan oluşur" (Bottomore ve Nispet, 2010: 356).

Park'ın üzerinde durulması gerekliliğin altını çizdiği göçün öznel boyutu ise, göçmenin ev sahibi toplumla olan kültürel etkileșimi sürecinde üretilen kișilik tipidir. Park, bu bağlamda farklı kültürlerin karşılaşması sonucu ortaya çıkan yeni kişilik tipini tartışmaya açmaktadır. Park'a göre yeni bir kültürel karşılaşma sırasında toplumun geleneksel düzeni dağılırken, bireysel insanı özgür bırakan bir etki yaratır. Daha önce gelenek ve adetler tarafindan kontrol edilen bireysel insan özgürleşir, serbest bırakılmış bir bireye dönüşür. Tıpkı Simmel'in 'yabanc1'sında olduğu gibi, dünyaya bir yabancının tarafsızlığıyla bakmayı öğrenir. Diğer yandan, kaçınılmaz olarak, serbest kalmış bireysel insanın yeni toplumsal düzenle yeniden bütünleşmesi gerekmektedir (Park, 2016: 75-76). Yeniden bütünleşme sürecinde "ilk deneyimlerdeki beklenti ve hayal kırıklığını nostalji ve sıla özlemi, yeni durumuna adım adım uyum sağlama, Amerikan yaşantısına ilk katılmalar, Amerikan toplumsal çevresinin firsatların arasında yeni dileklerin belirlenmesi, kişinin kendini sonunda anılar, hisler ve kabul edildiği ülkenin geleceği ile özdeşleştirmesi” izler (Park ve Burgess, 2017: 54). Ancak yeniden bütünleşme sürecinde, kültürel etkileşim ve asimilasyon her zaman aynı hızda ve kolaylıkta olmamaktadır. Özellikle karşılaşılan halkların farklı kültürel arka planlardan geldiği ve ırksal olarak da çeşitlilik gösterdiği birlikte yaşama deneyiminde, asimilasyon süreci daha problemli olmaktadır. Bu süreçte bireylerin kişiliklerinde de belirli değişimler meydana gelmekte, marjinal insan kişilik tipi ortaya çıkmaktadır (Park, 2016: 79). Bu kişilik tipinin tanımlanmasında, göçmenin içinde yaşadığı toplumdaki kültürel aidiyetinin oldukça önemli bir rolü vardır. Marjinal İnsan iki farklı kültüre sahip toplumda ortaya çıkan, yeni bir kişilik tipidir. Park'ın Marjinal İnsan tanımı şu şekildedir:

- "İki ayrı halkın farklı kültürel hayatı ve gelenekleri içinde samimiyetle yaşayan ve bu yaşamı paylaşan bir insan"

- "kendisine müsaade edilse bile geçmişinden ve geleneklerinden kopmaya pek istekli olmayan, kendine bir yer bulmaya çalıştığı yeni toplum içerisinde irksal önyargılar nedeniyle tam olarak da kabul edilmemiş bir insan"

- "hiçbir zaman iç içe geçmemiş ve kaynaşmamış iki kültür ve iki toplumun sınırlarında duran bir insandır" (Park, 2016: 80-81).

Park'a göre her göçmen başlangıçta eski alışkanlıklarından kopmaya çalışırken yenilerinin henüz oluşmadığı bir geçiş dönemi deneyimi yaşar. Bu dönemde göçmen ahlaki ikilik ve çatışma içerisindedir ve içsel bir çalkantı ve yoğun bir özfarkındalık ile karşı karşıya kalır. Bu nedenle başlangıçta her göçmen marjinal insandır, ancak göçmenin yaşadığı bu çatışma deneyimi geçici bir döneme karşılık gelir ve bu kriz hali zaman içerisinde dönüşür. Bir göçmeni marjinal insandan ayıran nokta, marjinal insanın durumunda kriz döneminin nispeten kalıcı olması, bu kriz halinin bir kişilik tipi haline dönüşme eğilimidir (Park, 2016: 82).

\subsection{Zygmunt Bauman: Düzenin İşgalcisi ve Belirsizliğin Sembolü Olarak Yabancılar}

Bauman'ın yabancılık tartışmalarında, düzen ve belirsizlik temaları ekseninde modern yabancılar ve postmodern yabancılar olmak üzere iki tür yabanc1lı türü ortaya konulur (Bauman, 2011; Bauman 2013; Bauman, 2014). Bauman modern öncesi ve modern dönemde yabancılık deneyimini Yahudi kimliği çerçevesinde ele alırken (Pietsch ve Marotta, 2009: 188), postmodern dönemde küreselleşme 
sürecinin etkileri sonucunda göçmenler, etnik kökeni farklı insanlar, serseriler, gezginler, evsizler, garip ve dikkat çeken alt kültürlerden olanlar (Bauman, 2014: 179) gibi farklı yabancı kategorileri de yer almaya başlar.

Bauman'ın Avrupa Yahudileri üzerinden tanımladığı modern yabancılar, modern dünya düzeninin yabanc1larıdır. Bauman'a göre modernite, düzen ile özdeşleşmiştir. Bu düzen, modern insanın hareketleri için düzenli ve istikrarlı bir çevredir. Toplumsal düzen içerisinde olayların meydana gelmeleri rasgele değil, sıkı bir hiyerarşiye göre dağılmıştır. Modern toplumsal yapının düzenliliği içerisinde birey, belli olayların muhtemelen olacağı, diğerlerinin daha az ihtimalle yaşanacağı, bazılarının ise neredeyse hiç yaşanmayacağını bilerek yaşamaktadır. Toplumsal yapıdaki düzen anlayışı, birey için de düzenli bir dünyayı ifade etmektedir. Böylece insanlar alışkın oldukları bir yaşam dünyası içerisinde, hayatlarını planlı bir şekilde yaşarlar, bu sayede kararlar alırlar ve güvende hissederler (Bauman, 2013: 16). Sınırları net bir biçimde belirlenmiş, her şeyin açık olduğu böylesi bir düzen anlayışının toplumsal alan ve ilişkilerdeki karşıllı̆ı ise, dışlanma pratiklerindeki belirleyiciliğidir.

Modern toplumsal yapının düzen anlayışı ve belirsizliğe karşı direnci, yabancıya yönelik bakış açısında da belirleyici olmuştur. Bauman yabancının konumlandırılışını, modern düzende kolektif kimliğin kategorik sınıflandırma anlayışı olan "biz" ve “onlar" ayrımı üzerinden ele almaktadır. Bauman'a göre yabancilar bu bölünmeye meydan okurlar. Onlar, her türlü bölünmeye, bölümleri muhafaza eden sınırlara ve bunların sonucunda ortaya çıkan sosyal dünyaya karşıdırlar. Sırf yerleşik hiçbir kategoriye kolayca uymayan yabancılar, kabul edilmiş zıtlıkların geçerliliklerini inkar ederler. Onlar ne yakın ne uzaktırlar. "Bizim" bir parçamız olmadıkları gibi “onlar"ın da bir parçası değildirler. Ne düşmandır, ne de dostturlar (Bauman, 2006: 65-66; Bauman, 2011: 112). Yabancı, iç grup ile dış grup arasındaki gri alandır. Bu alan anlaşılır bir biçimde faydalı bir rol oynayamaz; zararlı, niteliksiz olarak görülür. $\mathrm{Bu}$ grubun içinde, grubun kalıplarını kendisine "doğal" gösterecek herhangi bir statüye sahip değildir. Bu statüyü kazanmak için kalıbın gerektirdiği şekilde davranmak için çabalasa hatta, bunu başarsa bile, gruba, tam olarak dahil olması söz konusu değildir. Çünkü ne yaparsa yapsın grubun kendisinin bakış açısını yansıtma yetisini olduğunu kabul ettiremeyecektir (Bauman, 2013: 20). Onlarla tam olarak ne yapılacağı, onlardan ne beklenileceği, onlara nasıl davranılacă̆ yaşamaya alışık oldukları modern dünyada yabancı, bir belirsizliğe karşılık gelmektedir ve yabancının bilin(e)mezliği, toplumsal düzene tehdit olarak görülmektedir.

Modern toplumda düzen inşası, yabancılara ve yabancı olana karşı yürütülen bir aşındırma savaşına karşılık gelmektedir. Bauman'a göre düzenin yabancı ile savaşmasının iki yolu vardır. Birincisi asimilasyondur; yabancıların yutulması ve bu kişilerin kendilerinden ayırt edilemez bir doku haline dönüştürerek yok edilmesidir. Bauman asimilasyonu "farklıyı benzer kılmak; kültürel ya da dilsel ayrımları yumuşatmak; düzene uyumluluğu sağlayanlar dışında tüm gelenek ve bağlılıkları yasaklamak ve sadece tek bir uyumluluk ölçütü dayatmak" olarak tanımlamaktadır. Yabancı ile savaşmanın ikinci yolu ise, yabancıların kusulması ve içeride olanlarla tüm iletişimlerinin koparılmasıdır. Bunu yapmanın ise, iki yolu vardır: yabancıların gettoların görünür duvarlarının içine konulması ya da görünmeyen fakat en az bu duvarlar kadar somut olan birlikte yemek yeme, evlilik, ticaret yasaklarının ardına hapsedilmesi. Burada söz konusu olan yabancıların toprakların dışına sürülmesi ya da yabancıların fiziksel dışlanmasıdır (Bauman, 2013: 32-34). Bauman'a göre yutma stratejisi kapsayıcı, kusma stratejisi ise, dışlayıcıdır. Birincisi yabancıları "içeride" özümserken, ikincisi bunları dışarıya atar. İkisi birlikte yabancıları kutuplaştırır ve "içeri” ve "dışarı", "yurt” ve "yurt dışı", "biz" ve "onlar" kutupları arasındaki en sinir bozucu ve rahatsız edici orta alanı temizlemeye çalışır. Yaşam koşullarını ve seçimlerini kendilerinin tanımladığı yabancıları gerçek bir "ya o-ya bu" durumuna sokmaktadırlar: ya bize uyacaksınız ya da lanetleneceksiniz; ya bizim gibi olun ya da artık gidin, ya oyunu bizim kurallarımıza göre oynayın ya da oyundan tamamen atılmaya hazır olun. Bu iki strateji böylece toplumsal alanı gerçekten denetleme şansını yakalar. Dolayısıyla da bunların her ikisi de "her toplumsal tahakkümün araç çantasında mevcuttur” (Bauman, 2014: 246).

Postmodern döneme geçildiğinde ise, Bauman'ın yabancılık sosyolojisinde yabancıya ve yabancılarla birlikte yaşama deneyimine bakış farklılaşmıştır. Düzen anlayışında meydana gelen farklılaşma ve belirsizliğin başkalaşımı, Bauman'ın yabancıya ilişkin tartışmalarını dönüştürmüştür. Bauman'a göre günümüzde modern dönemin koşulları artık her yerde geçerli değildir. Postmodern dünyada günlük 
yaşam, bir zamanlar modern yapının temeli olan sağlamlık ya da süreklilikten yoksundur. Egemen olan ise düzen değil, yeni tip bir belirsizlik duygusudur. Diğer yandan bu belirsizlik, belli bir çabayla ya azaltılacak ya da tamamen üstesinden gelinecek sadece geçici bir dert olarak görülemez. Postmodern dünyada yaşamak, "daimi ve azaltılamaz bir belirsizlik koşulu altında yaşamaya hazırlanmaktadır" (Bauman, 2013: 36). Günümüzün yeni düzeni belirsizlik, kestirilemezlik ve istikrarsızlıktır ve bunlar, günümüz düzeninin yeni düşmanlarıdır (Bauman, 2011: 107). Belirsizliğin bu denli yayılışı, kolektif kimliklerin inşa süreçlerini de dönüştürmüştür. Bauman'a göre "post-modern dünyada normal ile anormal, beklenen ile beklenmedik, sıradan ile garip, evcil ile yabani ve nitekim aşina olunanla yabancı olan ve "biz" ile yabancılar arasındaki farklılık da bulanıklaşmaktadır" (2013: 41).

Modern yabancıların aksine postmodern yabancılar yok edilmesi gereken değil, faydalı görülen kişilerdir. Bunların yabancılıkları korunmalı ve üzerlerine titrenmelidir. Çünkü postmodern yabancılar, belirsiz ve karmaşık toplumsal düzen içerisinde, plansız ve istikametsiz yoldaki, olmazsa olmaz işaret direkleridir. "Artık sorun yabancıların ya da yabancılığın kökünün nasıl kazınacağı ya da insani farklılıkların geçici münasebetsizliklerinden başka bir şey olmadığının nasıl ilan edileceği değil, başkalıkla nasıl yaşanacağı sorunudur" (Bauman, 2013: 49).

Bauman postmodern dönemde yabancılarla birlikte yaşama deneyimini, kentsel alanlardaki mekânsal ayrışma dinamikleri ve tüketim ilişkileri üzerinden açıklamakta; bu bakımdan bu yeni düzende iki tür yabancı kategorisinden bahsetmektedir. Bauman'a göre günümüz kentleri hazzın ve tehlikenin, firsat ve tehdidin mekânıdır. Kent, içinde bulunan sakinlerine aynı tepsi içinde hem özgürlügün tadını hem heyecanı ve bitkinliği birlikte sunar (Bauman, 2014: 191). Bunun temel belirleyeni ise, kent içindeki hareket özgürlüğünün yarattığı tabakalaşmadır. Bauman kent içi hareketlilik ve tabakalaşma arasındaki ilişkiyi şöyle açıklar: "Kent sakinleri, yabancıların varlığını göz ardı edebilme ve işaretleri görülen tehlikeleri etkisiz hale getirebilme derecelerine göre tabakalaşırlar. Sorun, bunu yapmak için gerekli olan kaynakların kent sakinleri arasında eşitsiz biçimde dağıtılmış olmasıdır". Başka bir deyişle, bazılarının evleri, yabancılardan "kaçınma stratejisi" uygulamayacakları yerlerdedir (Bauman, 2011: 114; Bauman, 2014: 181). Hareketlilik özgürlüğü ve "kaçınma yeteneği”" korunduğu sürece, yabancıların varlı̆̆ ne kısıtlanır, ne rahatsız eder ne şaşırtırken, bu varlığın sağladığı çeşitli heyecan verici deneyim şansları memnunlukla karşılanabilir ve zevk verebilir". Bu durumda seçme özgürlügünün tadına varılabilir. Şöyle ki zengin semtlerde, güvenlikli ve korunaklı sitelerde çalışan/yaşayan postmodern kent sakinleri için "yabancı", haz verebilir ve asla tehdit edici değildir. Yabancilar heyecan veren damak zevkleri üreten restoran sahipleridir, partilerde kullanılabilecek gizemli şeyler satar, başka insanların yapmak istemeyeceği hizmetler sunarlar. Hizmetlerin tüketicisi patron, turist, müşteri olarak, yabancıların denetimini daima elinde tutar ve yabancılar ile karşılaşmanın ne zaman başlayacağına ve sona ereceğine karar verir. Hazların sağlayıcısı olan bu yabancıların varlığı için Tanrıya şükretmek gerekir (Bauman, 2011: 115).

Yabancıların sorun olarak görüldüğü yer ise, haz arayan tüketicilerin içinde yaşamaları biryana onların yaşadıkları yerleri ziyaret etmeleri bile asla mümkün olmayan kentin başka yerlerinde yaşayanlardır. Burada yaşayanlar, kiminle ne kadar süre karşılaşacaklarını seçemezler. Bu insanların kendi seçeneklerinin karşılı̆̆ını ödeme imkanı yoktur ve dünyayı bir macera parkı olarak değil, tuzak olarak görürüler. Burada yaşayan insanların için hiçbir çıkış yoktur, başkalarının rahatlıkla girip çıktığı bu bölgede hapsedilmiş güçsüz insanlar doludur. Tüketim toplumunun yasal ödeme aracı olan para, burada yaşayan insanlara yeterince arz edilmez. Bauman kent içi hareketliliği mümkün olmayan güçsüz insanların yabancıya bakışını şöyle açıklar: "Onların düşmanları, yani yabancılar ve davetsiz misafirler, kendi işe yaramaz zayıflıkları nedeniyle çok etkili ve güçlü görünürler; yabancıların görünüşteki becerikliliği ve kötü niyeti kendi güçsüzlüklerinin yansımasıdır. Kendi gözlerinde yabancıların müthiş gücü olarak kristalleşen, kendilerinin güçten yoksun oluşlarıdır" (Bauman, 2011: 116; Bauman, 2018: 15). Bauman'a göre postmodern kentin deneyimsel muğlaklığı, yabancının postmodern müphemliği olarak geri dönmektedir. Yabancının iki yüzü vardır. Birincisi ayartıcıdır çünkü gizemlidir ve kişiye hazzı vaat eder. Fakat tüm bunları yaparken hiçbir bağlılık yemini de talep etmez. Bu yüz sonsuz firsat, henüz denenmemiş haz ve yepyeni maceranın yüzüdür. İkinci yüz yabancı da gizemlidir. Fakat bu yabancıda gizem, ilkindeki haz getiren gizemliliğin aksine, uğursuzluğa, tehditkarlığa ve yıldırıcılığa karş1lık gelir (Bauman, 2014: 192). 
Bauman'a göre günümüz kentlerinin en kalabalık yabancıları, göçmenlerdir. Göçmenler her zaman yerlilere göre yabancıdır. Yabancıların özellikle kitlesel olarak gelenlerin, yerli halkın üzerinde yarattığı etkiyi Bauman değerler ve yaşam biçimi üzerinden okur. Ona göre, yerleşik halkın gözünden kitlesel yabancı akını değer verilen şeyleri yok edebilir ve bu benimsenen yaşam biçimini tehdit eder, Bauman'ın ifadesiyle "sakatlar ya da yok eder" (Bauman, 2018: 14). Yaşam biçimi, bildiğimiz, uyguladığımız ve el üstünde tuttuğumuz bir yaşama karşılık gelir ve göçmenlerin istilası bu yaşam şeklinin çöküş ve ölüm nedeni olarak sunulmaktadır (Bauman, 2018: 9). Yerli halk, yabancılarla karşılaşmadan önce yaşadığı mahalledeki, sokaktaki, iş yerindeki birlikte yaşamaya alıştı̆̆ insanları sıradan bir şekilde dost ve düşman olarak ayırabilir, bu kişileri ya hoş görür ya hor görür. Burada hangi davranış biçiminin benimseneceğinden çok, nasıl davranılacağının ve ilişkinin nasıl idare edileceğinin bilinmesi kilit önemdedir. Çünkü yabancılar işin içine girdiğinde bu nokta sorunlu hale gelir. Yabanciya dair bilgiler onların hareketlerini okuyacak kadar fazla değildir ve hangi tepkinin koyulmasının uygun olduğu durumu karmaşıktır. Niyetlerinin ne olduğu ve sonraki süreçlerde nasıl davranacaklarını tahmin etmek güçtür. Bu atmosferde, yerlide ortaya çıkan kayg1 ve korkunun en büyük nedeni ise, mevcut durumun kendilerinin eseri olmaması ve kontrolün de kendinde olmamasıdır (Bauman, 2018: 14-15). $\mathrm{Bu}$ bağlamda hem modern hem de postmodern düzenin yabancıları olan göçmenler, özellikle kitlesel zorunlu göçle gidenler, haz sağlayan ve korunması gereken yabancılar değil, gizemli ve tehditkar yabancilar kategorisinde yer almaktadır.

\section{Tartışma: Türkiye'deki Suriyelileri Sosyolojik "Yabancı" Olarak Ele Alma Sorunsalı}

Suriyelilerin, 2011 yılında başlayan kitlesel göçü her ne kadar başlangıçta geçici olarak görülse de, süreç içerisinde Türkiye'deki var oluşlarının geçicilikten kalıcılığa/yerleşikliğe doğru evrildiği gerçeği kabul görmüştür. Bu durum Suriyeliler ile Türkiye Cumhuriyeti vatandaşlarının birlikte yaşama ve bütünleşme deneyimlerine yönelik tartışmaları beraberinde getirmiş, bu birlikteliğe ilişkin akademik araştırmalar yapılmaya başlanmıştır. Türkiye için Suriyelilerin zorunlu kitlesel göçü gibi bir göç deneyiminin yeniliği karşısında göçmenlere bakış açısını anlamaya yönelik kuramsal tartışmalara ihtiyaç doğmuştur. $\mathrm{Bu}$ noktada da geleneksel göç ülkeleri olarak kabul edilmiş ülkelerde geliştirilen sosyolojik temelli kuramsal tartışmalar, kavramsallaştırma ve kuramsallaştırma bakımından başvuru kaynağı olmaya başlamıştır.

Uluslararası literatür incelendiğinde göçmenlere yönelik bakış açısını anlamada Georg Simmel, Robert Ezra Park ve Zygmunt Bauman gibi isimlerin öne çıktı̆̆ 1 ve göçmenin ağırlıklı olarak "yabancı" olarak değerlendirildiği görülmektedir. Nitekim Simmel, Park ve Bauman'ın yaklaşımları doğrudan "Yabanc1 Teorileri" (Theories of Stranger) adı altında ele alınmaktadır (Marotta, 2017). Yine konu birlikte yaşama deneyimi üzerinden yabancılık tartışmalarıyla zenginleştirilmektedir. Göçmen bu bağlamda içeride olan, ama aynı zamanda marjinal, ikincil konumda kalan, dışarıdaki, öteki olarak görülen kişidir (Rapoport ve Lomsky-Feder, 2001). Ancak "yabanc1" gibi bir kavram üzerinden konuyu ele almak ve teorik olarak tartışmak, Türkiye'nin özgün uluslararası göç deneyimini ve göçmene bakışını açıklamak bağlamında yeterli değildir. Yabancı teorilerinin birebir biçimde Türkiye deneyimine uygulanmasının birtakım sorun alanlarını beraberinde getirdiği yeni yapılan çalışmalarda da üzerinde durulmaktadır ${ }^{4}$.

Yabancı teorilerinin kullanımında sorun alanları olduğu düşüncesinin temel çıkış noktası, Türkiye'nin tarihsel bağlamda sözü edilen teorilerin ortaya çıktığı ülke deneyimlerinden oldukça farklı bir göç/göçmenlik deneyimine sahip olmasıdır. Simmel'in çalışması Almanya, Park'ın çalışması Amerika, Bauman'ın çalışması ise ağıllıklı olarak İngiltere örneğinde şekillenmiştir. Bu sosyologlar kendi ülke deneyimlerinden yola çıkarak, "yabancı"nın varlı̆̆ının sosyolojik koşullarını tarihsel, toplumsal ve

\footnotetext{
${ }^{4}$ Burada benzer bir düşünceyi tartışan Çakır'ın çalışmasına mutlaka değinmek gerekmektedir. Çakır'ın çalışması Simmel ve Bauman'ın yabancı tipolojisinin neden Türkiye'deki Suriyelilerin bütünleşmelerine ilişkin konularda kullanılamayacağını kuramcıların kuramlarına ilişkin bir tartışma yürüterek ve Türkiye özgülündeki farklılıkları ele alarak ortaya koymaktadır. Çakır'a göre Türkiye'deki Suriyeli sığınmacı nüfus için yabancı tipolojisi henüz oluşmamıştır. Bu nedenle kavramın kullanımında temkinli olmak gerekmektedir. Kavramın, sığınmacı sorununa olduğu gibi uygulanması teorik anlamda sorunları içermektedir. Bakınız: Çakır, H. (2017) Yabancı Kavramının Sığınmacı Sorunu Örneğinde Yeniden Değerlendirilmesi Üzerine, Route Educational and Social Science Journal, Vol: 4 No: 5, ss.187-197.
} 
kültürel arka planlarına dayanarak açıklamaya çalışmışlardır. Teorilerin ortaya çıktığı ülkelerin göç ve göçmenlikle olan ilişkisi bu bağlamda önem kazanmaktadır. Örneğin, Amerika, yüzyıllardır göç alan, uluslararas1 göçlerle oluşmuş bir ülkedir (Balibar, 2000: 119). Türkiye özgülünde ise, her ne kadar kuruluşundan bu yana göç deneyimi olan bir ülke olduğu kabul görse de, Batı Avrupa ülkeleri ve Amerika gibi uzun bir tarihsel sürece yayılan ve ulusu, etnisite temelinde kendisinden farklı olan göçlerle oluşmuş bir göç/göçmenlik deneyiminden söz edilememektedir. 1923-1980 dönemi gibi oldukça uzun bir tarihsel süreç içerisinde Türkiye, ulus devlet inşa projesinin bir parçası olarak Türk soyundan olma ve/veya Türk kültürüne bağlı olma temelinde göçmen kabulünü benimsemiştir. 1980'li yıllara gelindiğinde ilk kez Türk ve/veya Müslüman kimlikli olmayanların, yani “yabancı”ların göçü ile karşı karşıya kalmıştır (Erder, 2007; Kirişçi, 2008; İçduygu, 2010). Kabul gören göçmen kimliği, etnisite temelinde Türklük ve Müslümanlık ekseninde şekillenmiştir. 2000'li yıllarda ise, Türkiye'ye yönelik göçlerin giderek arttığ 1 ve çeşitlendiği gelişmeler meydana gelmiş, Türkiye, Afrika ülkeleri gibi komşu olmadığı uzak coğrafyalardan da göçmenleri ağırlamaya başlamıştır. En yoğun göç dalgası ile ise 2011 y1lı sonrası Suriyelilerin kitlesel zorunlu göçü ile karşıllaşmıştır. Tarihsel olarak Türkiye, son birkaç yıla kadar Suriyelileri geçici olarak görme eğilimi göstermiş, Suriyelilerin Türkiye'deki yaşamları ve Türkiye toplumuna entegrasyonu yeni yeni tartışılmaya başlanmıştır. Oysa göçmenler ile birlikte yaşam ve entagrasyon tartışmaları sözü edilen ülkelerde oldukça uzun bir tarihsel geçmişe sahiptir. Bu ülkelerde uzun süreli kalıcılık deneyiminde farklı göçmen kuşakları ve göçmen azınlık grupları oluşmuştur. Göçmenlerin yabancı olma hallerine ilişkin tartışma alanları bu tarihsellik içerisinde gelişmiştir. Tarihsel olarak mevcut olan bu farklılaşma, Türkiye deneyiminin yeniliğinin ve farklılaşan göç/göçmen politikaları geleneğinin, teorik tartışmalar temel alınırken göz önünde bulundurulması gerekliliğine işaret etmektedir. Çünkü Castles ve Miller'ın da ifade ettiği gibi, "etnik farklılığın toplumsal olarak ne anlama geldiği, göç alan devletlerin ve toplumların bu farklılığa bakış açısına bağlıdır". Örneğin, Amerika, Kanada, Avustralya gibi klasik göç ülkeleri, Avrupa kökenli olmaları şartıyla, göçmenleri entegre ya da asimile edilecek sürekli yerleşimciler olarak görür (2008: 19-20). Dolayısıyla ülkelerin tarihsel bağlamda göçle karşılaşma, göçmeni tanımlama ve kabul biçimleri, birlikte yaşama deneyiminde oldukça önemli bir belirleyendir.

Göçün tarihsel geçmişinin yanı sıra etkili olan bir diğer nokta, göçün ve/veya göçmenin niteliğidir. Sözü edilen teorilerin neredeyse tümünde merkeze alınan göçmenler "emek göçmenleri"dir. Emek göçmenleri, daha iyi bir yaşam umuduyla ülkelerinden başka bir ülkeye istihdam amaciyla göç eden göçmenlerdir. Ekonomik göçmen olarak da tanımlanan emek göçlerinin en önemli özelliği ise çoğunun devlet tarafindan hukuksal olarak düzenlenmesidir (IOM, 2004: 38). Türkiye'ye yönelik gerçekleşen Suriyelilerin göçü ise, emek göçü değil, zorunlu göç kapsamında yer almaktadır. Üstelik emek göçlerinden farklı olarak kitlesel bir niteliğe sahiptir. Suriyelilerin kitlesel zorunlu göçü, sadece Türkiye için olmayıp tüm dünya ülkeleri için oldukça ciddi bir göç deneyimine karş1lık gelmektedir. Birleşmiş Milletler Mülteciler Yüksek Komiseri Filippo Grandi (2018), Suriyelilerin zorunlu göçünü insanlığın karşı karşıya kaldığı en büyük mülteci krizi göçü olarak tanımlamaktadır. Göçün niteliği bağlamında, tüm dünya ülkeleri için yeni olan bir deneyime karşıllık gelmektedir. Dolayısıyla göçmenlere yönelik bakış açısını yeniden şekillendiren önemli bir etkiye sahiptir. Çakır'ın da üzerinde durduğu gibi artık göçün öznesinin "çeşitli ülkelerden gelen çeşitli kültürlere mensup kimseler değil, benzer kültürel gruplardan gelen milyonlarla ifade edilen nüfuslar" olması söz konusudur. Bu yeni gelişme ile birlikte klasik göç ülkeleri olarak kabul gören Avrupa ülkeleri içinde oluşan kuramsal yaklaşımların da Suriyelilere ilişkin açıklamalarda yeniden gözden geçirilmesine ihtiyaç vardır. Sonuçları itibariyle, sosyoloji literatürü içerisinde yer alan kuramsal yaklaşımlar, Suriyeli göçmenlere ilişkin açıklamalar ile tam olarak uyuşmamaktadır (2017: 189-190). Dolayısıyla sadece Türkiye için değil, Suriye'den göç alan tüm ülkeler için göçmenlere yönelik bakış açısını anlamaya yönelik yeni teorik tartışmalara ihtiyaç olduğu söylenebilir. Öte yandan, Suriyelilerin emek göçmeni olmayıp zorunlu göçmen olmaları, Türkiye'de yaşam deneyimlerinin uluslararası alanla da ilişkilenmesini beraberinde getirmektedir. Suriyeliler, sadece Türkiye'nin birlikte yaşadığı bir göçmen grup değil, aynı zamanda uluslararası toplumun da sorumlu olduğu ve yaşamlarına katkı sağladığı bir göçmen grubudur. Dolayısıyla Suriyelilerin toplumsal pozisyonlarına ilişkin çıkarımlar, Suriyeli göçünün kendi özgünlüğü ve yarattığı ilişkilerin niteliği ile birlikte değerlendirilmelidir. 
Kuramsal yaklaşımların Türkiye özgülünde uygulanabilirliklerini tartışırken üzerinde durulması gereken bir diğer önemli boyut, yaklaşımların konuyu sosyolojik olarak (epistemolojik-metodolojik dayanağı/temel aldığı toplumsal grup/ülkenin ulusal geleneği vb.) ele alma biçimleridir. Bu kapsamda ele alınan kuramsal yaklaşımları, yukarıda yer alan tartışmaların tekrarına düşmeden, konuyu sosyolojik olarak açıklayıcılıkları bağlamında tek tek ele almak yararlı olacaktır.

Simmel'in yaklaşımı ${ }^{5}$ gündelik yaşamda meydana gelen etkileşim biçimlerinden oluşan "bir toplumsal tip olarak yabancı"ya dayanmaktadır. Esasen burada yabancı, Simmel'in toplumun oluşumuna sosyolojik olarak bakışının bir parçası olarak karşımıza çıkmaktadır. Çalışmaları çoğunlukla gündelik yaşam sosyolojisi ile ilişkilendirilen Simmel'in sosyolojisinin en belirgin özelliği, gündelik etkileşimlerden daha geniş toplumsal yapılar inşa etmesidir (Ritzer ve Stepnisky: 2013: 44). Onun sosyolojisinde toplumun kalıcı mirasını oluşturan devlet, aile, ekonomi, sınıf yapısı gibi toplumsal kurumlar, ofislerde, sokaklarda, dükkânlarda ya da partilerde karşılaşan kadın ve erkeklerin günlük etkileşimlerinin kapsamının genişletilmiş şeklidir (Collins ve Makowsky: 2014: 143). Başka bir şekilde ifade etmek gerekirse, toplumu oluşturan dinamik, insanların gündelik yaşamdaki toplumsal etkileşimleridir. Görünüşte önemsiz gözüken insanların birlikte yemek yemesi, birbirlerine yol tarifi sormaları, başkalarına kendilerini beğendirmek için giyinmeleri gibi gündelik hayattaki davranışlar toplumsal etkileşimleri ortaya çıkarır. Simmel'e göre insanları birbirine bağlayan bu tür etkileşimlerdir. Bu tür davranışlar sürekli yaratılır, düzenlenir ve farklı etkileşim biçimleriyle değiştirilir. Simmel'e göre bu etkileşimler toplumsal hayatın atomlarıdır (Ritzer ve Stepnisky: 2013: 40). Ona göre dünya, sayısız olaylar, etkileşimler ve benzerlerinden oluşur. İnsanlar gerçekliğin üstesinden gelmek için gerçekliğe, tarzlar ve biçimler yükleyerek ona bir düzen verirler. Eyleyenin çoğunlukla şaşırtıcı olay ve durumlarla karşılaşmamasını sağlayan da budur. Simmel'e göre sosyologun görevi, toplumsal gerçekliğe, daha özel olarak etkileşime sınırlı sayıda biçimler dayatmaktır. Bunu yapmak, toplumsal gerçekliğin daha iyi çözümlenebilmesini sağlar. Bu yöntembilimi genel olarak çok çeşitli belirgin etkileşimle içerisinde bulunan ortaklıkların seçilip çıkarılmasını kapsar (Ritzer, 2014: 276). Simmel'in etkileşime sınırlı sayıda biçimler dayatılması düşüncesinin sosyolojik yaklaşımındaki karşılığı ise, toplumsal tiplerdir. $\mathrm{Bu}$ sayede toplumsal tipler etkileşime dayalı birliktelik biçimleri olarak karşımıza çıkmaktadır.

Simmel'in sosyolojisinde yabancı tipi, tarihsel olarak varlığını sürdüren, farklılaşan toplumsal durumlarda oluşma ve yeniden-oluşma sürecinde olan ancak her ne olursa olsun aynı kalan bir öze sahip olan bir formu temsil eden ve aynı tepkiyi yaratan tiplerdir. Örneğin yabancı tipi, ister kabile Afrika'sında ister modern Avrupa'da olsun aynı şekilde etiketlenen ve tepki verilen bir tiptir (Slattery, 2010: 54). Tüm bu tartışmalarda Simmel'de yabancının yapısalcı bir yaklaşımda ele alındığı görülmektedir. Simmel, toplumsal ilişkilerin evrensel bileşenlerinden biri olarak yabancıyı açıklarken, yabancılığın yapısal bir teorisini ortaya koymaya çalışır. $\mathrm{O}$, yabancıların deneyimleri ile ilgilenmez, yabancının içerideki ve dişarıdaki olarak ikili pozisyonunu ele alarak, yabancının yeni grup ile olan ilişkileri aracılığıyla gelişen toplumsal pozisyonuna odaklanır (Rapoport ve Lomsky-Feder, 2001; Alexander, 2004: 87). Simmel'de yabancının sosyolojik kavramsallaştırması, aynı kültürel bilgiyi, varsayımları ve dünya görüşünü paylaşmayan bir bireyin, bir toplumsal sistem içerisinde bulunduğu belirgin bir toplumsal statüye işaret eder (Davidson ve Garcia, 2014: 1). Böyle bir statü, yalnızca dışarıdakini içeridekinden ayırmaz, aynı zaman da grupların sınırlarını yeniden işaretler ve çizer (Rapoport ve Lomsky-Feder, 2001: 7). Bu bağlamda yabancl, Simmel'in gündelik yaşamdaki etkileşimleri anlayabilmenin bir aracı olarak tanımladığı metodolojik bir öğedir. Dolayısıyla, doğrudan göçmenlikle ilişkili tartışmalara uyarlanması sorgulanmaya açıktır.

\footnotetext{
${ }^{5}$ Türkiye'deki Suriyeliler üzerine yapılmış çalışmalarda Simmel'in "yabancı" kavramını kullanan bazı çalışmalar için bakınız: Altunkaynak, S. (2016) Intersectıng Lives in Post-Migration Period: The Dynamics of Relations Between "Host" Women From Turkey And "Guest" Women From Syria, Alternatif Politika, Cilt: 8 Sayı:3, ss.488504; Göker, G., Keskin, S. (2015) Haber Medyası ve Mülteciler: Suriyeli Mültecilerin Türk Yazılı Basınındaki Temsili, İletişim Kuram ve Araştırma Dergisi - Sayı 41 / Güz 2015, ss.229-256; Ekinci, Y. vd. (2017) Yabancı ve Marjinal Olarak Öteki: Yerleşik ve Yabancı İlişkisi Bağlamında Suriyeli Sığınmacılar, Tarih Okulu Dergisi, Yıl: 10, Sayı: XXX, ss. 365-392; Kaya, M. (2017) Türkiye'deki Suriyeliler: İç İçe Geçişler ve Karşılaşmalar, İstanbul: Hiperlink Yayınları.
} 
Simmel'in yabancı toplumsal tipi ve Türkiye deneyimindeki uygunluğu konusunda üzerinde durulması gereken bir diğer önemli nokta, Simmel'in yabancıyı toplumsal ilişkilerin evrensel bileşenlerinden biri olarak görmesidir. Simmel burada Yahudi örneğini vermektedir (Simmel, 2009: 154). Ancak Türkiye deneyiminde tarihsel olarak varlığını sürdüren, farklılaşan toplumsal durumlarda oluşma ve yenidenoluşma sürecinde olan ancak her ne olursa olsun aynı kalan bir öze sahip olan bir formu temsil eden ve aynı tepkiyi yaratan Yahudi toplumsal tipi gibi bir tipe benzer göçmen grubundan henüz söz edilememektedir. Öte yandan Yahudi toplumsal tipi, Hıristiyan olan Alman toplumunda etno-kültürel ve dinsel farklılıkları olan bir tipe karşılık gelmektedir. Türkiye özgülünde ise, her ne kadar etnik ve kültürel köken bağlamında Suriyeliler farklı bir toplumsal gruba karşılık geliyorsa da, din temelinde iki toplumun benzerliği söz konusudur (Erdoğan, 2015: 112). Bu benzerliğin birlikte yaşama sürecine nasıl bir etki edeceğini kesin bir şekilde ortaya koyabilmek şu an için zordur. Çakır'a göre de Simmel'in yabanc1 için vermiş olduğu örnekler oldukça tarihsel ve metodolojiktir. Bu durum Türkiye'deki Suriyeli sığınmacı grubun “yabancı" olarak ifade edilmesini sosyolojik olarak imkansız kılmaktadır. Türkiye'nin göç deneyimi henüz söz edilen tarihsel ve toplumsal olgunluğa ulaşmamıştır (2017: 194).

Park'ın marjinal insan yaklaşımı ${ }^{6}$ ele alındığında ise, farklı kültürel arka plana sahip göçmen gruplarının Amerikan toplumu ile bütünleşme dinamiklerinin açıklanmasını temel aldığı görülmektedir. $\mathrm{Bu}$ dönemde Chicago kenti İtalyanlar, İrlandalılar, Polanyalılar, Ukraynalılar ağırlıklı olmak üzere yoğun bir emek göçü ile karşı karşıya kalmıştır. Amerika'nın işgücü ihtiyacını karşılayacak olan göçmenlerin asimilasyonu bir devlet politikası olarak da ele alınmıştır. Ancak Türkiye'de Suriyelilerin göçü planlanan ve denetlenen bir göç olmanın ötesinde kitlesel ve zorunlu bir göçtür. Bu nedenle Suriyeli göçü oldukça kısa olan tarihi içerisinde Suriyelilerin bütünleşmesinden çok beraberinde getirdiği sorunları ile ele alınmıştır. Türkiye'nin tarihsel olarak da entegrasyon politikaları adı altında bir politika üretim alanına sahip olduğunu söylemek güçtür. İlk olarak Suriyelilere yönelik 2014 y1lında yürürlüğe giren Yabancılar ve Uluslararası Koruma Kanunu (YUKK) kapsamında entegrasyon politikaları başlı̆g yer almıştır. Oysa Park'ın yaklaşımının ortaya çıktığı dönem göç alan tüm dünya ülkelerinde asimilasyon politikalarının tartışıldığı bir dönemdir ve üzerinden geçen uzun zaman içerisinde göçmenlik koşullarında meydana gelen önemli değişiklikler söz konusudur. Kısaca ifade etmek gerekirse, göçlerin ve göçmenlerin niteliği değişmiş, küresel hale gelen uluslararası göç hareketleri giderek artan bir biçime sahip olmuştur. Ayrıca, bu süreç içerisinde asimilasyon politikalarının başarılı olmadığı kabul edilmiş, sonrasında kültürel çoğulculuk devamında ise çok kültürlülük tartışmaları yapılmaya başlanmıştır. Dolayısıyla, Park'ın eninde sonunda kültürel asimilasyonun gerçekleşeceğine dayanan yaklaşımı günümüzde oldukça tartışmalıdır.

Yaklaşımın güncelliğinin sorgulanmadığı varsayıldığında ise, Park'ın yaklaşımının Türkiye deneyimine uygulanabilirliği bağlamında iki nokta üzerinde durmak gerekir. İlk olarak, Park'ın marjinal insan tanımını ele almak yerinde olacaktır. Park'a göre marjinal insan iki ayrı halkın farklı kültürel hayatı ve gelenekleri içinde yaşayan, kendine bir yer bulmaya çalıştığı yeni toplum içerisinde irksal önyargılar nedeniyle tam olarak da kabul edilmemiş ve hiçbir zaman iç içe geçmemiş ve kaynaşmamış iki kültür ve iki toplumun sınırlarında duran bir insandır (Park, 2016: 80-81). Suriyeliler özgülünde 1rksal önyargılar bağlamında "Arap" olma bir etken olarak görülebilir ancak diğer yandan Suriye kültürü ile Türkiye kültürünün birbirinden farklılığının sorun olarak görülmesi tartışmaya açıktır. Her iki toplumun nüfuslarının önemli bir kısmının Müslüman olması, Türkiye toplumunun Suriyelilere bakışını belirleyen önemli bir ortaklıktır. Dedeoğlu ve Ekiz Gökmen'in Azeri göçmenler ile yaptıkları araştırmalarında da Azerilerin büyük çoğunluğunun Müslüman olmasının toplumsal bütünleşmelerini kolaylaştırıcı bir etken olduğunu ortaya çıkmıştır. Aynı çalışmada Türkiye’ye Eski Doğu Bloğu ülkelerinden gelen göçmen kadınlar, yaşam tarzları üzerinden "Nataşa" gibi etiketlemelere maruz kalırken, Azeri kadınların Müslüman oldukları vurgusu ile bu tür etiketlemelerden uzak kaldıkları saptanmıştır (2011: 127). Diğer yandan her iki toplumun da 1rk/etnik köken bağlamında homojen toplumlar olmaması durumu da belirleyici görünmektedir. Türkiye'de Cumhuriyet'in kuruluşundan bu yana yaşayan ve Türkiye'nin kendi vatandaşı olan Arap kökenli insanlar bulunmaktadır. Ayrıca, hem Türkiye'de hem Suriye'de Kürt

\footnotetext{
${ }^{6}$ Suriyeliler üzerine yapılmış çalışmalarda Park'ın marjinal insan kavramını kullanan bazı çalışmalar için bakınız: Ekinci, Y. vd. (2017) Yabancı ve Marjinal Olarak Öteki: Yerleşik ve Yabancı İlişkisi Bağlamında Suriyeli Sığınmacılar, Tarih Okulu Dergisi, Yı1: 10, Sayı: XXX, ss. 365-392; Kaya, M. (2017) Türkiye'deki Suriyeliler: İç İçe Geçişler ve Karşılaşmalar, İstanbul: Hiperlink Yayınları.
} 
ve Türk etnik kökenli insanlar yaşamaktadır. Türkiye'nin özellikle Güneydoğu Bölgesi kentlerinde yaşayan vatandaşları ile Suriye sınırında yaşayan insanlar arasında akrabalık bağları bulunmaktadır (Erdoğan, 2015: 113). Bu bağlamda, bir Suriyeli bir göçmenin kültürel olarak farklı görünme biçimi Türkiye'nin her yerinde geçerli bir durum olarak tanımlanamaz. Kahya Nizam'ın İzmir'de yürüttügü alan araştırmasında Türkiyeli Arap görüşmecilerin bazıları tarafından Suriyeliler ile yemek kültürlerinin oldukça benzer olduğuna dikkat çekilmiştir. Yine bazı görüşmeciler, Suriyeli kadınların ikinci eş olarak yaşamalarına "çok eşlilik bizim oralarda da zaten vardır" şeklinde yaklaşmıştır. Dolayısıyla bir göçmen grubun "yabancı", "marjinal insan" gibi bir kategoride tanımlanabilmesi noktasında kentsel dinamikler, örneklem grubunun sosyo-demografik özellikleri gibi değişkenlerin göz ardı edilmemesi ve sınırlı sayıda görüşmeden yola çıkarak genellemelere gitmek yerine çok fazla sayıda araştırma yapılarak belli bir birikimselliğinin oluşması gerekmektedir. Bu bağlamda, bir göçmen kategorisinin tümünün bir kişilik tipine indirgemek noktasında dikkatli olunmalıdır.

Üzerinde durulması gereken ikinci nokta, Park'ın tüm göçmenleri başlangıçta yeni bir topluma uyum sağlamaya çalışırken marjinal insan konumunda olarak görmesi ancak süreç içerisinde toplumun eritme potası sayesinde bu durumun dönüşerek kriz halinin sona ereceğini ileri sürmesidir. Bu yaklaşım doğrultusunda Suriyeliler her ne kadar başlangıçta marjinal insan olsa da süreç içerisinde bu durum ortadan kalkacak, Türkiye toplumu ile kaynaşarak toplumun ayrılmaz bir parçasına dönüşecektir. Uzun vadede birlikte yaşayan, aynı ekonomiyi paylaşan iki toplum, kültürel ve ırksal olarak melezlenecek, böylece kaçınılmaz olarak siyasal, ekonomik ve kültürel asimilasyon her anlamda gerçekleşecektir. Dolayısıyla farklı bir ırksal ve kültürel arka plana sahip bir Suriyeli sadece bundan dolayı marjinal insan olarak konumlandırılamaz. İki toplum arasındaki sosyal temasın ve kültürel etkileşimin dönüşümünün nasıl olacağ kestirilemez niteliktedir. Suriyelinin bir marijinal insan kişilik tipi olarak ele alınabilmesi için uzun bir tarihsel deneyime ihtiyaç vardır. Nitekim Park emek göçü ile gelen birçok farklı göçmen grubundan söz ederken marjinal insan kişilik tipine örnek olarak Yahudi'yi vermektedir (Park, 2016: 80). Bu örneklendirme bir göçmen kategorisinin marjinal insan olarak değerlendirilebilmesi bağlamında tarihsel deneyimin belirleyiciliğine dikkat çekmesi bakımından aydınlatıcıdır.

Bauman'ın yaklaşımı Türkiye toplumunun Suriyeli göçmenlere yönelik bakış açısını ortaya koymak için yapılan çalışmalarda sıklıkla kullanılmaktadır ${ }^{7}$. Araştırmalarda Türkiye deneyiminde Suriyeliler, Bauman'ın post modern yabancılar olarak tanımladığı ve haz alınan yabancılar olarak gördügü yabancılar olmaktan uzak bir konumda ele alınmaktadır. Modern düzen anlayışı içindeki tehditkar ve belirsizliğin sembolü olan modern yabancılara daha fazla karşıllk gelir gibi görünmektedir. Bu durum ise, Bauman'ın yaklaşımının evsahibi toplum ile göçmenler arasındaki toplumsal alan ve ilişkileri anlamaya çalışırken daha çok göçmenlere yönelik dışlama pratiklerindeki belirleyiciliği ile ele alınmasına yol açmaktadır.

Bauman yabancıya ilişkin tartışmalarında her göçmenin yerliye göre yabancı olduğunu, özellikle kitlesel zorunlu göçle giden göçmenlerin, yerliler tarafindan yaşam tarzına tehdit olarak görüldüğünü ifade etmektedir. $\mathrm{Bu}$ bağlamda Suriyeliler, göçün niteliği bağlamında, hazzın taşıyıcısı olan gizemli yabancılar değil, tehdit ve belirsizliğin sembolü olan yabancılardır. Ancak Bauman'ın yabancıya bakış1 kuramsal bütünlüğü içinde ele alındığında bazı sorgulamaları gerektirmektedir. Bauman'ın yaklaşımında modern yabancılar savaşılması gereken gruplar olarak görülmektedir. Yabancılarla savaşmanın ise iki yolu vardır: Yutma/Asimilasyon ya da Kusma/ Dışlama. Yabancıların yutulması yani asimile edilmesini Bauman, farklının benzer kılınması, kültürel ya da dilsel ayrımların yumuşatılması, düzene uyumluluğu sağlayanlar dışındakilerin tüm gelenek ve bağlılıklarının yasaklanması ve sadece

\footnotetext{
7 Türkiye'de Suriyeliler üzerine yapılmış çalışmalarda Bauman en fazla referans gösterilen isimdir. Bauman'ın yabancısını kullanan bazı çalışmalar için bakınız: Man, F. (2015) "Günah Keçileri” ya da "Olağan Şüpheliler" Olarak Suriyeliler, Çalışma ve Toplum, 2016 (3), s. 1147-1169; Ekinci, Y. vd. (2017) Yabancı ve Marjinal Olarak Öteki: Yerleşik ve Yabancı İlişkisi Bağlamında Suriyeli Sığınmacılar, Tarih Okulu Dergisi, Y1l: 10, Sayı: XXX, ss. 365-392; Ünal, S. (2014) Türkiye'nin Beklenmedik Konukları: "Öteki" Bağlamında Yabancı Göçmen ve Mülteci Deneyimi, Zeitschrift für die Welt der Türken Journal of World of Turks, Vol: 6, No: 3, pp.65-89; Gözübüyük Tamer, M. (2016) Trabzon Kamuoyunun Geçici Koruma Kapsamındaki Suriyelilere Bakış Açısı, Karadeniz Araştırmaları Enstitüsü Dergisi, 2016/2, s. 180-211.
} 
tek bir uyumluluk ölçütünün dayatılması olarak tanımlamaktadır (Bauman, 2013: 32). Oysa Türkiye'de Suriyelilere yönelik kapsamlı bir asimilasyon beklentisi henüz olgulanlaşmamıştır. Suriyeliler kültürel olarak Türkiye toplumuna uyum sağlayamayan kişiler olarak görülse de Suriyelilerin geleneklerinin yasaklanması ya da kültürel olarak Türkiyelilere benzetilmesi konusunda bir dayatma ya da kriter belirme durumundan söz edilemez. Diğer yandan bu noktada, Türkiye kültürünün ne kadar homojen olduğu konusu da tartışmaya açıktır.

Bauman'a göre yabancılarla savaşın ikinci yolu olan kusma/dışlama ise, yabancıların gettoların görünür duvarlarının içine konulması ya da görünmeyen fakat en az bu duvarlar kadar somut olan birlikte yemek yeme, evlilik, ticaret yasaklarının ardına hapsedilmesi gibi eylemlerle görünür olan fiziksel olarak dışlanmadır. Bu uygulamada yabancıların toprak dışına sürülmesi ve tüm iletişimlerinin koparılması esastır (Bauman, 2013: 32). Türkiye halk1 tarafından Suriyelilerin ülkelerine geri gönderilmeleri, kamplarda tutulmaları, yerli halkla bir arada yaşamamaları gibi dışlayıcı söylemler mevcutsa da uygulamada gettolaşmaya benzer bir yapılanma söz konusu değildir. Nitekim Türkiye, Bauman'ın ulus devletlerin yabancılara yönelik temel stratejisi olarak tanımladığı temizleme yerine, ümmetçilik anlayışıyla Suriyelilere açık kapı politikası uygulayarak ve ülkenin farklı kentlerinde yaşamalarına izin vererek bunun tam karşısında bir yerleşim politikasını esas almıştır. Yerleşimlerine izin verilmesinin yanında Suriyelilerin eğitim, sağlık, barınma ihtiyaçlarının karşılanması konusunda ciddi bir çaba sarf etmiştir. Ayrıca, Türkiye toplumunun bir parçası olma bağlamında önemli bir adım olarak Suriyelilere Türk vatandaşlığı da verilebilmektedir. 1 Ağustos 2019 tarihi itibarıyla 47 bini yetişkin, 45 bin 280'i çocuk olmak üzere toplam 92 bin 280 Suriyeliye Türk vatandaşlığ verilmiştir (Mültecider, 2019). Dolayısıyla Suriyelilerin durumunun Bauman'ın yabancı yaklaşımı kapsamında değerlendirilmesinin nasıl dönüşeceği belirsiz bir duruma karşıllk gelmektedir. Suriyeliler henüz ne özümsenme ne de dışarıya atılma aşamasındadır. Yerli halkta "içeri” ve "dışarı", "biz" ve "onlar" kutuplaşması oluşmuşsa da Suriyelilerin temizlenmesi gereken grup olarak dönüşüp dönüşmeyeceğini ve yabancılık ilişkisinin nasıl şekilleneceğini görmek için zamana ihtiyaç vardır.

Diğer yandan yabancı Bauman tarafindan Simmel'inkine benzer olarak modernite eleştirisi bağlamında ortaya konulmuş, bu doğrultuda olumsuz bir anlamda ele alınmıştır. Her iki sosyoloğun da yaklaşımlarında yabancı, etnik ve dini azınlıklar gibi içinde bulunduğu toplumla tarihsel bir bağa sahip insan gruplarını ifade etmek için kullanılmıştır (Çakır, 2017: 187). Suriyelilerin henüz Türkiye toplumunda bir göçmen-etnik azınlık statüsü içerisinde tartışılması söz konusu değildir. İki toplum arasında Osmanlı Devleti döneminden kalan tarihsel bir bağ söz konusu ise de iki ülke toplumunun farklılaşan ulus devletleşme deneyimleri bulunmaktadır. Bu tarihsel bağın, Suriyelilerin Türkiye içerisindeki göçmenlik deneyimini nasıl dönüştüreceği izlenmelidir. Çakır'ın da belirttiği gibi, "Bauman'ın yaklaşımı, her ne kadar sosyolojik içerimleri bulunsa da, ampirik olarak değil, tarihsel olarak sınanabilir bir yabancı okumasidir" (2017: 193).

Yabancılık teorilerinin Türkiye'deki Suriyelilere doğrudan uyarlanmasının teorik bağlamda sorun alanlarına değindikten sonra "yabancı" kavramının yapılan araştırmalardaki kullanımına ilişkin bazı noktalara değinmek yerinde olacaktır. İlk olarak, bazı çalışmalarda (Kahraman ve Kahya Nizam, 2016) Türkiye'nin Türk soyundan ve/veya Türk kültürüne bağlı olma kriteri bağlamında değişen göçmen profiline referansla "yabancı" olarak adlandırılan göçmenlerin doğrudan Simmel'in "yabancı"sı ile özdeşleştirildiği görülmektedir. Türkiye'deki göç araştırmacılarının 1980 sonrası dönemde göçle gelenlerin değişen niteliğine vurgu yaptıkları yabanc1, Türk ve Müslüman olmayan kişilere (İçduygu, 2014: 56) karş1lık gelmektedir. Dolayısıyla Türkiye'ye gelen ve etnisite temelinde farklı olan her göçmen grubunun Simmel'in yabancı toplumsal tipine karşıllk gelecek şekilde ele alınması sorunludur. Kavramın genel bir tanımı üzerinden gidildiği böyle bir kullanımın, kavramın ortaya çıktı̆̆ özgün deneyimi göz ardı ettiği ve indirgemeci bir kullanıma yol açtığı söylenebilir.

Türkiye'deki çalışmalarda Simmel'in yabancı kavramı kullanılırken gösterilen bir diğer eğilim, yabancı toplumsal tipinin geliştirildiği koşullar ve kuramsal bütünlüğü göz ardı edilerek, tartışmanın belli kısımlarının Türkiye'deki Suriyelilere uyarlanmasıdır. Örneğin, Göker ve Keskin (2015), Simmel'in yabancı tanımında yer alan "bugün gelip yarın giden gezgin gibi değil, bugün gelip yarın kalan insan gibidir" kısmındaki kalıcılık vurgusundan yola çıkarak, Suriyelilerin Türkiye'deki kalıcılıkları arasında bir bağlantı kurmaktadır. Her ne kadar hukuksal statüleri geçici korunan olarak tanımlansa da 
Suriyelilerin tümünün ülkelerine dönmelerinin olanaklı olmadığına dikkat çeken yazarlar, kalış süresinin uzaması ile birlikte Türkiye toplumunda Suriyelilere yönelik olumsuz ve gerilimli düşüncelerin arttığına ve bu ilişki ağı içerisinde Suriyelilerin Simmel'in toplumsal tipi olan yabanciya dönüştüklerini ileri sürmektedir. Bir diğer çalışma da (Altunkaynak, 2016) yine Suriyelilere yönelik geçicilik söyleminin gerçeklikle uyuşmadığı üzerinden yola çıkarak, Suriyelilerin kalıcılığına ve yeni "yabancı grubun" diğer topluluklar ile nasıl uyum sağlayacağına odaklanılmasına gerektiğine dikkat çekmektedir. Hatay ve Gaziantep'teki Suriyeli ve Türkiyeli kadınlarla yapmış olduğu alan araştırmasının kuramsal arka planını Simmel'in yabancı toplumsal tipi üzerine kurgulayan Altunkaynak (2016), Simmel'in grubun üyesi olma bağlamında ele aldığı yabancılık ilişkisini, örneklem grubu ekseninde içerideki ve dişarıdaki ilişkisi üzerinden değerlendirmektedir. Yazara göre, Türkiye toplumunda Suriyelilere ilişkin terörizm, seks işçiliği, hırsızlık, suçluluk oranları, üniversitelere ücretsiz erişim, işsizlik gibi alanlarda etiketlemeler artmakta, bu süreç de iki toplum arasındaki sosyal etkileşimde olumsuz bir etki yaratmaktadır. Diğer yandan, kamusal alandaki misafirlik söylemi nedeniyle her iki toplum aralarındaki ilişkiye geçici olarak bakarken, Suriyelilerin geçmişlerinden kopamamalarına ve yeni alanda ilişkiler kuramamalarına neden olmaktadır. Her iki toplum arasındaki olumsuz etkileşim biçimi ise, Suriyelilerin Simmelci anlamda yabancı olarak tanımlanmasını sağlamaktadır. Simmel'in yabancı toplumsal tipini Türkiye'deki Suriyelilere uyarlayan bir diğer çalışma, Ekinci ve arkadaşlarının (2017) Gaziantep ve Kilis'te yapmış oldukları alan araştırmasının sonuçlarından yola çıkmaktadır. Alan araştırmasının bulgularına göre, görüşmeciler Suriyelilerin kendi aralarındaki farklılıkları göz ardı etmekte ve Suriyelileri "yabancı sığınmacı" adı ile tek bir kategori olarak değerlendirmektedir. Simmel'in yabancının bir birey olarak değil, bir toplumsal tip olarak görülmesi tartışmasını Türkiye'ye uyarlayan yazarlara göre, bu bağlamda Suriyeliler Simmelci anlamda belli bir tipte yabancıya karşıllk gelmektedir. Yazarlar, Suriyelilere ilişkin meydana gelen tekil olayların tüm Suriyelilere genellenmesi üzerinden savlarını güçlendirmektedirler. Farklı kentlerde Suriyelilere yapılan saldırıları da tüm Suriyelilerin tek bir toplumsal tip olarak görülmeleri ile açıklamaktadırlar. Kavramın bu çalışmada kullanımına ilişkin bir değerlendirme yapılacak olursa, göçmen grubun tümünün tek bir kategoride ele alınmasından başlanabilir. Türkiye deneyiminde 1990 sonrasında eski Sovyet ülkelerinden gelen göçmen kadınların da tek bir kategoride tanımlandıkları ve "Nataşa" olarak etiketlendikleri yapılan çalışmalarda (Dedeoğlu ve Ekiz Gökmen, 2011) ortaya konmaktadır. Ancak, Suriyelilere göre oldukça uzun bir tarihsel geçmişe sahip olmalarına rağmen bu göçmen grubunun Simmelci anlamda bir toplumsal tip olarak yabanciya dönüştüğünü söylemek güçtür. Bu durumda 8 yıl gibi kısa bir birlikte yaşama deneyiminden yola çıkarak Suriyelileri tek bir kategori adı altında tanımlamak ve Suriyeliyi bir toplumsal tip olarak yabancı ile özdeşleştirmek için zamana ihtiyaç vardır. Bir diğer üzerinde durulması gereken nokta, araştırmaların yapıldığı kentte yaşayan sınırlı örneklem grubundan elde edilen bulgulardan yola çıkarak genellemeler yapılmasıdır. Örneklem grubunun sınırlılı̆ğ, demografik özellikleri ve kentsel dinamikler göz ardı edilerek araştırma bulgularından Suriyelileri toplumsal bir tip olarak yabancı ile özdeşleştirmenin indirgemeci bir yaklaşımı beraberinde getirdiği söylenebilir.

Simmel'in toplumsal tip olarak tanımladığı yabancının doğrudan Suriyelilere uyarlanması ile ilgili sorgulanması gereken bir noktanın daha üzerinde durmak yerinde olacaktır. Simmel, bir toplumsal tip olarak yabacıyı somutlaştıırıken Yahudi örneğini vermekte ve Yahudilerin karşı karşıya kaldıkları ayrımcılığ 1 ele alırken "Yahudilerin farklılaşan ve ağırlaşan vergi yükümlülükleri, belirli nesnel içeriklerin taşıyıcısı olmasıyla değil, her şeyden önce bir Yahudi olmasından dolayıdır" (2009: 154) demektedir. Türkiye deneyiminde Suriyelilere yönelik söylem ve pratikler ekseninde onları bir yabancı olarak değerlendirirken bu noktayı göz önünde bulundurmak gerekmektedir. Suriyeliler belirli nesnel içeriklerin taşıyıcısı olarak mı Türkiye toplumu tarafından dışlanmaktadırlar, yoksa her şeyden önce bir Suriyeli oldukları için mi?

Kavramın geliştirildiği sosyolojik koşullar ve kuramsal bütünlüğü göz ardı edilerek, tartışmanın belli kısımlarının Türkiye'deki Suriyelilere uyarlanması sorunu, Park ve Bauman'ın yabancılık tartışmalarını kullanan çalışmalarda da görülmektedir. Örneğin, Ekinci ve arkadaşları (2017), alan bulgularından yola çıkarak farklı bir kültürel arka plana sahip Suriyelilerin, Türkiye kültürü ile Suriye kültürünün farklılıkları arasında sıkıştığını ve marjinalleştiğini, bu bağlamda Park'ın marjinal insan tipine uygun olduklarını ileri sürmektedirler. Yazarlara göre, Türkiye'ye kendi alışkanlıkları ve gelenekleriyle gelen 
Suriyelilerin yerleştikleri yerlerde kültürel olarak uyum sağlayamaması ve ırksal ve kültürel önyargılar nedeniyle tam olarak kabul görmemesi onları marjinal bir konuma sürüklemektedir. Bu noktada Park'ın marjinal insan tartışmasında yer alan "her göçmen başlangıçta marjnal insandır" fikri Suriyelilerin durumunu açıklamaya uygunmuş gibi görünse de, çoğu göçmen grup için eninde sonunda kültürel asimilasyonun sağlanacağ 1 ve marjinalliğin ortadan kalkacağı Park'ın tartışmasının temelini oluşturmaktadır. Nitekim kendisi de, oldukça farklı göçmen kategorileri ile karşılaşan Amerikan toplumunda marjinal insanın en tipik ve tarihsel örneği olarak Yahudi'yi tanımlamaktadır. Dolayısıyla farklı bir kültürel arka plana sahip olmaları, Suriyelileri başlangıçta Türkiye kültürü karşısında marjinalleştirse de, uzun vadede Suriyelilerin Park'ın tanımlamasıyla marjinal insan kişilik tipine uygun olup olmayacağı kestirilemez niteliktedir. 8 yıl gibi oldukça kısa bir birlikte yaşama deneyiminden yola çıkarak böyle bir tanımlamaya gitmek indirgemeci bir yaklaşım olacaktır.

Kaya (2017) da alan araştırmasına dayanan çalışmasında araştırma bulgularını yorumlarken Simmel ve Park'ın yabancılık tartışmalarından yararlanmaktadır. Yazar, Suriyeli kadınların Türkiyelilerle çok eşli olarak yaşamlarını sürdürmelerini, Simmel ve Park'ın yabancının sonradan gittiği ülkenin gelenekleri, dinsel teamülleri, norm ve değerlerine doğrudan bağlı olmadığı, kutsallık içeren ilişkilerin sekülerleşmesi tartışmasına bağlamaktadır. Yazara göre göç sonrasında meydana gelen bu özgürleşme, Suriyeli kadınların Türkiye toplumunun değerlerine kayıtsız kalarak ve onları çiğneyerek yaşamlarını sürdürmeleri için uygun bir zemin hazırlamaktadır. Oysa hem Simmel hem de Park'da yabancının katıldığı toplumdaki bu özgürleşme süreci, olumsuz bir duruma karşılık gelmemekte, aksine yakınlıkuzaklık ilişkisi ekseninde yabancının en temel sosyolojik özelliklerinden biri olan nesnelliğine vurgu yapmak için kullanılmaktadır. Bu özelliği sayesinde yabancı, toplumsal önyargılardan bağımsız olarak katıldığı toplumdaki olay ve durumları tarafsız bir bakışla değerlendirebilme şansına sahip olmaktadır (Simmel 2009: 151; Park, 2016: 76). Nitekim Simmel, yabancının nesnelliğine örnek olarak bazı İtalyan şehirlerinde yargıçların dişarıdan getirilmesini örnek verir (2009: 151). Her iki yabancı tartışmasında da göçmenin gittiği ülke toplumunun değerlerini ve normlarını çiğneme ve kayıtsız kalma özgürlüğü kazanması gibi olumsuzlayıcı bir çıkarım söz konusu değildir.

Yine Bauman'ın yabancılık tartışmaları Türkiye'deki Suriyelere yönelik bakış açısının anlaşılmasından en yoğun kullanılanlar arasındadır. Bauman'dan yararlanan bazı çalışmalara (Ünal, 2014; Man, 2015; Kahraman ve Kahya Nizam, 2016; Gözübüyük Tamer, 2016; Ekinci vd., 2017) bakıldığında, kimlik temelinde "biz-onlar-yabancı" ayrımı tartışması bağlamında, Suriyelilerin ne bizden/dost ne onlardan/düşman oldukları, yabancılıklarının beraberinde getirdiği belirsizlik ve tehdit algısı karşısında Türkiye toplumu tarafından dışlandıkları ortaya konmaktadır. Gözübüyük Tamer (2016)'in Trabzon, , Kahraman ve Kahya Nizam (2016)'ın Gaziantep'te, Ekinci ve arkadaşlarının (2017) Hatay ve Kilis'te yaşayan halkın Suriyelilere bakışını ele aldıkları araştırma sonuçlarında, görüşmecilerin Suriyelilerle komşu olma, evlenme/çocuğunu evlendirme, alışveriş yapma gibi sosyal temaslardan kaçındıkları ortaya konmuştur. Araştırmacılar, bulgularını Bauman'ın yabancı ile fiziksel yakınlıktan kaçınma, fiziksel yakınlığın olduğu durumlarda ise, manevi ayrılığı koruma ve yabancılardan ayrı yaşama düşüncesi etrafında yorumlamaktadır. Suriyeliler, Biz ve onlar ayrımını bulanıklaştırarak yabancılar olarak konumlanmakta ve pis, tehlikeli, hastalıklı kişiler olarak modernite anlayışının temizlemek istediği yabancılar olarak somutlaşmaktadır. Ekinci vd. (2017) Suriyelilere yönelik dışlama pratiklerini Baumancı perspektiften Arapça tabelaların yerleşik halkının çoğunun da Arap olduğu bazı belediyeler (Gaziantep, İzmir, Hatay, Adana belediyeleri) tarafından kaldırılmak istenmesiyle örneklendirmektedir. Daha önce de üzerinde durulduğu gibi, Bauman'a göre kitlesel zorunlu göçle giden göçmenler, yaşam tarzına tehdit olarak algılanmaları ve belirsizliğe karşılık gelmeleri nedeniyle yabancıdır. Ancak Suriyelilerin zaman geçtikçe yabancılık derecelerinin nasıl olacağ 1 ve temizlenme projesinin bir parçası olup olmayacağının anlaşılması için zamana ihtiyaç vardır. Nitekim Bauman'ın yabancıya ilişkin tartışmalarında devletlerin göçmenlere yönelik politikaları oldukça belirleyicidir. Türkiye'deki Suriyeliler deneyiminde ise, Suriyelilere yönelik hükümet politikası, Bauman'ın tartışmasında olduğu gibi dışlayıcı ve temizleme amaçlı olmaktan ziyade ümmet-din temelinde birleştirici bir söylemi içermektedir. 


\section{SONUÇ}

Türkiye'de Suriyeliler ile ilgili yapılan sosyolojik araştırmalarda, Suriyeli kimliği Simmel, Park ve Bauman'ın "yabancı" kavramı ile birlikte ele alınmakta ve çoğunlukla olumsuz bir etkileşim ve birliktelik biçimi ekseninde tanımlanmaktadır. Araştırmaların kuramsal arka planları inşa edilirken ise, yabancılık tartışmalarının ortaya çıktı̆̆ 1 ve geliştiğ i tarihsel bağlamın ve "yabancı" olarak tanımlanan grubun özgünlüğünden bağımsı olarak Türkiye'deki Suriyelilere doğrudan uyarlandığı görülmektedir. Türkiye'deki Suriyeliler, kitlesel zorunlu göçle gelen göçmenler olması bağlamında göçün yoğunluğu, zorunluluğu, uluslararası alanın ilgisinde olmaları, devletlerarası ilişkiler, iki toplum arasındaki tarihsel, toplumsal, siyasal ve ekonomik etkileşim bağlamında kendi özgünlügü ile ele alınması gereken bir gruba karşılık gelmektedir. Yabancı teorilerin ortaya çıktığı ve geliştiği ulusal bağlamda "yabancı" olarak tanımlanan grubun sosyolojik özelliklerinin, Türkiye'deki Suriyelilere ne derece uyarlanabileceği bu bağlamda göz önünde bulundurulmalıdır. Suriyelilerin toplumsal pozisyonlarına ilişkin çıkarımlar, Suriyeli göçünün kendi özgünlüğü ve yarattığı ilişkilerin niteliği ile birlikte değerlendirilmelidir.

Diğer yandan, göçmen grubun göç edilen toplumla temasının tarihsel olarak uzunluğu, o göçmen grubun sosyolojik anlamda "yabancı" olarak değerlendirilip değerlendirilemeyeceği noktasında belirleyicidir. Suriyelilerin Türkiye'deki 8 y1llık geçmişlerinden yola çıkarak, Suriyelileri bir toplumsal tip olarak "yabancı" ya da "marjinal insan" olarak tanımlama noktasında acele edilmemelidir. Suriyelilerin "yabancı" olarak dönüşüp dönüşmeyeceği belirsizdir. Yabancı kavramını kullanan çalışmalara bakıldığında kavramın genel bir tanımı ve betimleyiciliği üzerinden gidildiği ve özgün deneyimindeki açıklayıcılığının göz ardı edildiği görülmektedir. Türkiye'nin ve yabancılık sosyolojisinin geliştirildiği ülkelerin özgün deneyimi göz önünde bulundurulmadan doğrudan bu tartışmaların Suriyeliler örneğine uyarlanması, indirgemeci bir bakış açısını beraberinde getirme riskini barındırmaktadır. Bu nedenle kavramın genel bir kullanımı yerine, boylamsal düzlemde çok sayıda araştırma yapılmasına ve yeni kavram setlerinin geliştirilmesine ihtiyaç vardır. "Yabancı" kavramının açıklayıcılığı göz ardı edilmeden, farklı ülke deneyimlerinin özgünlüğü ortaya konularak Türkiye deneyiminin bir karşılaştırma içerisinde değerlendirilmesi daha doğru olacaktır. 


\section{KAYNAKÇA}

Açıkgöz, R. vd. (2017). Türkiye'deki Suriyeli Mültecilerin Yaşam Koşulları Üzerine Sosyolojik Bir Çalışma: Elazı̆̆ Örneği. Route Educational and Social Science Journal, 4 (4), 84-99.

Alexander, J. C. (2004). Rethinking Strangeness: From Structures in Space to Discourses in Civil Society. Thesis Eleven, Number 79, 87-104.

Altunkaynak, S. (2016). Intersectıng Lives in Post-Migration Period: The Dynamics of Relations Between "Host" Women From Turkey And "Guest" Women From Syria. Alternatif Politika, Cilt: 8 Say1:3, 488-504.

Apak, H. (2014). Suriyeli Göçmenlerin Kente Uyumları: Mardin Örneği. Mukaddime, 5 (2), 53-75.

Bakioğlu, A., Artar, F., İzmir, H. (2018). Ankara'daki Suriyelilerin Mültecilik Deneyimleri: Göç, Gündelik Yaşam, Geçim Deneyimleri ve Sosyal Dışlanma. Sosyoloji Derneği Yayınları, Yayın No: 25.

Balibar, E. (2000). Irk Ulus Sinıf Belirsiz Kimlikler. Ed. Etienne Balibar ve Immanuel Wallerstein, Nazlı Ökten (Çev.), 3. Baskı, İstanbul: Metis Yayınları.

Bauman, Z. (2006). Sosyolojik Düşünmek. Abdullah Yılmaz (Çev.). İstanbul: Ayrıntı Yayınları.

Bauman, Z. (2011). Bireyselleşmiş Toplum.Yavuz Alogan (Çev.). 2. Basım. İstanbul: Ayrıntı Yayınları.

Bauman, Z. (2013). Postmodernizm ve Hoşnutsuzlukları. İsmail Türkmen (Çev.). 2. Baskı. İstanbul: Ayrint1 Yayınları.

Bauman, Z. (2014). Parçalanmış Hayat. İsmail Türkmen (Çev.). 2. Baskı. İstanbul: Ayrıntı Yayınevi.

Bauman, Z. (2018). Kapımızdaki Yabancılar. Emre Barca (Çev.). İstanbul: Ayrıntı Yayınları.

Bottomore, T. ve Nisbet, R. (2010). Sosyolojik Çözümlemenin Tarihi. Mete Tunçay ve Aydın Uğur (Yayına Hazırlayan). 2. Baskı. İstanbul: Kırmızı Yayınları.

Castles, S. , Miller, M.J. (2008). Göçler Çağı Modern Dünyada Uluslararası Göç Hareketleri. 1. Baskı. İstanbul: Bilgi Üniversitesi Yayınları.

Collins, R., Makowsky, M. (2014). Toplumun Keşfi. Prof. Dr. Nurgün Oktik (Çev. Ed.), Ankara: Nobel Akademik Yayınc1lık.

Çakır, H. (2017). Yabancı Kavramının Sığınmacı Sorunu Örneğinde Yeniden Değerlendirilmesi Üzerine. Route Educational and Social Science Journal, Vol: 4 No: 5, 187-197.

Çetin, İ. (2016). Türkiye'de Suriyeli Sığınmacıların Sosyal ve Kültürel Entegrasyonu. Sosyoloji Dergisi, Say1: 34, 197-222.

Davidson, T., Garcia, C. (2014). Welcoming The Stranger Religion and Attitudes toward Social Justice for he Immigrants in the U.S. Journal of Religion \& Society, Vol: 16.

Dedeoğlu, S., Ekiz Gökmen, Ç. (2011). Göç ve Sosyal Dışlanma Türkiye’de Yabancı Göçmen Kadınlar. Ankara: Efil Yayınevi. 
Ekinci, Y. vd. (2017). Yabancı ve Marjinal Olarak Öteki: Yerleşik ve Yabancı İlişkisi Bağlamında Suriyeli Sığınmacılar. Tarih Okulu Dergisi, Y11: 10, Sayı: XXX, 365-392.

Erder, S. (2007). "Yabancısız" Kurgulanan Ülkenin "Yabancıları". Aylan Arı (der). Uluslararası Göç, İşgücü ve Nüfus Hareketleri içinde. İstanbul: Derin Yayınları.

Erdoğan, M.M., (2015). Türkiye'deki Suriyeliler Toplumsal Kabul ve Uyum. İstanbul: Bilgi Üniversitesi Yayınları.

Göker, G., Keskin, S. (2015). Haber Medyası ve Mülteciler: Suriyeli Mültecilerin Türk Yazılı Basınındaki Temsili. İletişim Kuram ve Araştırma Dergisi - Sayı 41 / Güz 2015, 229-256.

Gözübüyük Tamer, M. (2016). Trabzon Kamuoyunun Geçici Koruma Kapsamındaki Suriyelilere Bakış Açısı. Karadeniz Araştırmaları Enstitüsü Dergisi, 2016/2, 180-211.

Grandi, F. (2018). Suriye Acil Durumu, https://www.unhcr.org/tr/suriye-acil-durumu. 19 Nisan 2018 tarihinde güncellenmiş, Erişim Tarihi: 08.05.2019.

IOM (2004). Glossary on Migration, İnternational Migration Law Series. No: 25, Geneva.

İçduygu, A. (2010). Türkiye’ye Gelen Uluslararası Göçün Toplumsal ve Siyasi Koşulları, iç. Türkiye’ye Uluslararası Göç Toplumsal Koşullar -Bireysel Yaşamlar içinde, (der. Barbara Pucsh, Tomas Wilkoszewski), çev. Mutlu Çomak-Özbatır, İstanbul: Kitap Yayınevi.

İçduygu, A. (2014). Bir Siyaset ve Siyasa Alanı Olarak Uluslararası Göç: Son Yüzyılda Dünya ve Türkiye. iç. Türkiye'nin Uluslararası Göç Politikaları 1923-2023: Ulus-Devlet Oluşumundan Ulus-Ötesi Dönüşümlere. Mirekoç Araştırma Raporları, 1/2014.

Kahraman, F., Kahya Nizam, Ö. (2016). "Mültecilik Hallerini Mekan Üzerinden Okumak: Gaziantep Örneğinde Türkiyelilerin Gözünden Suriyeli Kent Mültecileri". Uluslararası Sosyal Araştırmalar Dergisi, Haziran 2016, Cilt:9, Say1:44, 808-825.

Kaya, M. (2017). Türkiye'deki Suriyeliler: İç İçe Geçişler ve Karşıllaşmalar. İstanbul: Hiperlink Yayınları.

Kirişçi, K. (2008). Osmanlı ve Cumhuriyet Türkiye'sinde Göç ve Sığınma. Düşünce Gündem Mültecilik Özel Sayısı. Sayı: 44, Y11: 4, Temmuz 2008, s. 12-15.

Man, F. (2015). "Günah Keçileri” ya da "Olağan Şüpheliler” Olarak Suriyeliler. Çalışma ve Toplum, $2016(3), 1147-1169$.

Marotta, V. P. (2017). Theories of the Stranger: Debates on Cosmopolitanism, Identity and CrossCultural Encounters. New York: Routledge.

Mültecider (2019). Türkiye'deki Suriyeli Sayıs1 Eylül 2019. https://multeciler.org.tr/turkiyedekisuriyeli-sayisi/, (29.09.2019).

Park, R.E. (2016). İnsan Göçü ve Marjinal İnsan. iç. Yabancı Bir İlişki Biçimi Olarak Ötekilik, der. Levent Ünsald1. Ankara: Heretik.

Park, R. E, Burgess, E.W. (2017). Asimilasyon ve Sosyal Kontrol-Sosyoloji Bilimine Giriş II. çev. Pınar Sayar Kızılçalı. 1. Baskı, İstanbul: Pinhan Yayınları. 
Park, R. E. (2019). Yalıtım ve Sosyal Temaslar -Sosyoloji Bilimine Giriş V. çev. Gökçe İnan Yağlı, 1. Bask1, İstanbul: Pinhan Yayınları.

Pietsch, J., Marotta, V. (2009). Bauman, Strangerhood and Attitudes towards Immigrants among the Australian Population. Journal of Sociology, Vol: 45, No: 2, 187-200.

Rapoport, T., Lomsky-Feder, E. (2001). Reflections on Strangeness in Context: The Case of RussianJewish Immigrants in the Kibbutz. Qualitative Sociology, 24(4): 483-506.

Ritzer, G. (2014). Klasik Sosyoloji Kuramları. çev. Himmet Hülür. Ankara: De Ki Basım Yayın.

Ritzer, G., Stepnisky, J. (2013). Çağdaş Sosyoloji Kuramları ve Klasik Kökleri. çev. Irmak Ertuna Howison, Ankara: De Ki Basım Yayın.

Sağır, A., Kurtkara, S. (2018). Sosyoloji Bölümü Öğrencilerinin “Suriyeli” Kavramına İlişkin Tutumları Üzerine Sosyolojik Bir Çözümleme (Bülent Ecevit Üniversitesi Ve Karabük Üniversitesi Örneği). Uluslararası Sosyal Araştırmalar Dergisi, Cilt: 11, Sayı: 60, 648-661.

Simmel, G. (2009). Yabancı, iç. Bireysellik ve Kültür. çev. Tuncay Birkan, İstanbul: Metis Yayıncılık.

Tümtaş, M. S. (2018). Toplumsal Dışlanmadan Vatandaşlık Tartışmalarına Suriyeli Kent Mültecileri. Akdeniz İ.İ.B.F. Dergisi (37), ss. 26-47.

Türk Vatandaşlı̆̆1 Kanunu (2009) https://www.mevzuat.gov.tr/MevzuatMetin/1.5.5901.pdf, (26.09.2019).

Weisberger, A. (1992). Marginalty and its Directions. Sociological Forum, Vol: 7, No: 3, pp. 425-446.

Ünal, S. (2014). Türkiye'nin Beklenmedik Konukları: "Öteki" Bağlamında Yabancı Göçmen ve Mülteci Deneyimi. Zeitschrift für die Welt der Türken Journal of World of Turks, Vol: 6, No: 3, 65-89.

Yabancilar ve Uluslararas1 Koruma Kanunu https://www.mevzuat.gov.tr/MevzuatMetin/1.5.6458.pdf, (26.09.2019).

(2013) 